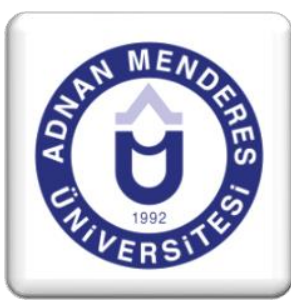

\title{
Türkiye Kamu Yönetiminde Yönetişim Algisi: Aydin İli Vergi Dairelerinde Bir Uygulama
}

\author{
Hakan ARSLANER ${ }^{1}$, Yakup KARACA ${ }^{2}$
}

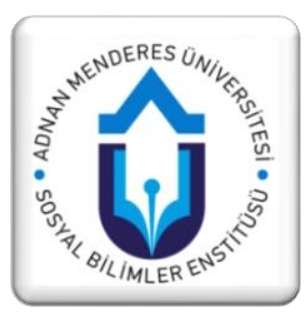

\section{ÖZET}

Dünyada küreselleşme ile birlikte yaşanan çok yönlü değişim ve dönüşümlerden kamu yönetimi de etkilenmektedir. Bu bağlamda etkin/etkili ve verimli bir yönetim anlayışına dayanan Yeni Kamu İşletmciliği modeli çerçevesinde kamu yönetiminde yapılan reformların bir sonucu olarak yönetişim yaklaşımı ortaya çıkmıştır. Bu yaklaşım kamuda, yönetim ve karar alma süreçlerinde birlikte karar alma, işbirliği ve katılımı hakim kılmak, Yöneten ve yönetilenin karşılıklı etkileşim içinde olduğu temelinde yöneticilerin, sorumluluk, etkinlik, verimlilik, saydamlık, açıklık, hesap verilebilirlik ve hukukun üstünlüğü ilkeleri kapsamında bir yönetim anlayış1 içerisinde hareket etmelerine dayanmaktadır. Devlet ve vatandaşın karşılıklı etkileşimde bulunduğu en yoğun alanların başında vergi gelmektedir. Vatandaşlar vergi dairelerinde işlemlerini gerçekleştirirken idarenin desteğine ve ilgisine ihtiyaç duymaktadır. İdare ve vatandaş arasında Sağlıklı iletișimin gerçekleșmesi ve etkin, verimli bir hizmetin sağlanması için vergi daireleri büyük öneme sahiptir. Bu hususta vergi dairesi sağlıklı bir düzen hakim kılabilmesi için vergi mevzuatlarının açık olması, daire yöneticileri ve çalışanlarının işbirliğini hakim kılması gerekmektedir. Bu çalışmanın amacı Aydın ili özelinde vergi dairesi; müdürleri, müdür yardımcıları, gelir uzmanları ve avukatlarının vergi dairelerinden yönetişim perspektifinde beklentilerini ortaya koyarak değerlendirmektir.

Anahtar Kelimeler ; Yönetişim, Gelir İdaresi, Vergi dairesi

Jel Kodlar1 ; H20, H30, K34

\section{Perception of Governance in Turkish Public Administration: An Application at Tax Offices in Aydin Province}

\begin{abstract}
Public administration is influenced by all-around changes and transformations with the globalization across the world. In this context, the approach of governance has emerged as a result of the reforms conducted in the public administration in accordance with the New Public Business Administration which is based on an efficient/effective and productive management understanding. This approach is based on the idea that administrators act in accordance with an administration approach involving the principles of responsibility, efficiency, productivity, transparency, clarity, accountability and rule of law for the purpose of ensuring mutual decision-making, cooperation and participation and interaction between those who administer and are administered in public institutions. Tax is one of the primary domains in which the interaction between the state and citizens is at its highest. Citizens are in need for the support and attention of the administration when transacting at tax offices. Tax offices are of great importance for the performance of healthy communication between the administration and citizens and providing an effective and efficient service. In this sense, it is required that tax legislations are clear and cooperation between office administrators and employees is dominant so that a healthy order can be achieved in transactions at the tax offices. This study aims to shed light on and evaluate the expectations of tax office managers, assistant managers; revenue experts and lawyers from tax offices with regards to governance specifically in Aydın province.
\end{abstract}

Keywords ; Governance, Revenue Administration, Tax office

Jel Codes $\quad$; H20, H30, K34

\footnotetext{
${ }^{1}$ Yar.Doç.Dr. Adnan Menderes Üniversitesi Nazilli İ.İ.B.F

${ }^{2}$ Öğr.Gör. Adnan Menderes Üniversitesi Çine Meslek Yüksek Okulu
} 


\section{Giriş}

1980’li y1ların öncesinde sadece özel sektörde geçerli olan etkinlik/etkililik ve verimlilik arayışları, son yıllarda Kamu sektöründe yaşanan değişimin bir sonucu olarak ortaya çıkan Yeni Kamu İşletmeciliği modeli olan yönetişim yaklaşımıyla kamu sektöründe de kendisini göstermeye başlamıştır. Bu yaklaşımın temelini etkinlik kavramı oluşturmaktadır. Yaklaşım çerçevesinde etkinliği sağlayan olgular ise hesap verilebilirlik, katılımcılık, vatandaşların karar alma süreçlerinde rol alması, şeffaflık, denetim ve hukukun üstünlüğü gibi kavramlardır. Kamu sektöründe giderek hız kazanan vatandaş odaklılık, birlikte karar alma, toplam kalite anlayışının yaygınlaşması katılımın farklı düzeylerde yaşama geçirilmesini ve kamu hizmetlerinde vatandaş memnuniyetinin sağlanmasını zorunlu kılmaktadır.

Yeni kamu yönetiminin amacı yöneteşimci bir yaklaşımla toplumsal refahı, huzuru tahsis etmek, karar alma süreçlerinde vatandaşında katılımını ve memnuniyetini sağlamak, kamunun kaynaklarını etkin ve verimli bir şekilde kullanmak ve sürdürülebilir kılmak olduğundan, kamu kurum ve kuruluşlarının bu doğrultu da amaçlarını ne ölçüde gerçekleştirdiklerini hedeflerini, stratejilerini ve faaliyetlerini başarılı bir şekilde gerçekleştirip gerçekleştirmedikleri önem arz etmektedir.

$\mathrm{Bu}$ çalışmanın amacı Kamu kayaklarının en etkin şekilde kullanılıp kamu hizmetlerinin vatandaşlara en verimli şekilde sağlanması arayışı içinde olan yeni kamu yönetimi anlayışından hareketle Aydın ili özelinde vergi dairesi; müdürleri, müdür yardımcıları, gelir uzmanları ve avukatlarının vergi dairelerinden yönetişim perspektifinde beklentilerini ortaya koyarak değerlendirmektir. 


\section{Yönetişim Kavramı}

Küreselleşme ile birlikte hız kazanan çok yönlü değişim dinamikleri tüm toplumların gerek sosyo-ekonomik gerekse kültürel hayatında önemli dönüşümlere yol açmakta, kamu yönetimine ilişkin kavram ve değerler ile kamu örgütleri de bu dinamiklerden yakından etkilenmektedir. Hızlı nüfus artışı ve kentlere yapılan göçler sonucunda toplumun daha etkili ve kaliteli hizmet taleplerinin artması, kamu kurum ve kuruluşlarının bu talepleri karşılamada yetersiz kalması, kamu hizmetlerinin vatandaşların gözünde yavaş, kalitesiz, pahalı ve ulaşılması zor olarak görülmesi, devlete biçilen yeni roller, kamuya ayrılan kaynakların yetersizliği kamu yönetimini değişmesi yönünde sürekli bir baskı altında tutmaktadır. Öte yandan kamusal harcamaların artması sonucu mali sistemde ortaya çıkan sıkıntılar ve bilgi iletişim teknolojilerinde yaşanan hızlı değişimin her yönüyle toplumsal yaşama girmesi kamu yönetiminde bir değişimi zorunlu kılmaktadır. Geleneksel kamu yönetimi yaklaşımına getirilen eleştiriler yerelliği, esnek çalışma biçimlerini, yatay örgütlenmeyi, uzmanlaşmayı ön plana çıkaran kamu yönetimi anlayışını gündeme getirmektedir. Günümüz kamu yönetimi anlayışında saydamlık, açıklık, katılımcılık, hesap verebilirlik, esneklik, kamu kaynaklarının kullanımında etkinlik ve verimlilik yükselen değerler olarak yerini almaktadır. Küresel değişim dinamiklerinin zorlamasıyla yeniden yapılanma arayışına giren kamu kesiminin tanık olduğu yaklaşımlardan birisi de Yönetişimdir (DPT, 2007: 1).

Kavram, kamu yönetimi disiplinine 1980'li yılların sonuna doğru Yeni Kamu İşletmeciliği ve Kamu Tercihi Teorisi ile birlikte girmiştir.

Etkin ve verimli bir kamu yönetimi anlayışına dayanan yeni kamu yönetimi ya da kamu işletmeciliği akımlarının sonucu olarak kamu yönetiminde yenidünya düzenine uyum sağlamayı amaçlayan reformlar yapılmıştır. Bu süreç içerisinde yönetişim kamu yönetiminin neredeyse tümüne egemen olmaya başlamıştır. Yerel yönetimlerin gittikçe artan katılım isteklerini karşılayabilmek için, hemen her ülkenin bu yönde kendilerini gözden geçirdikleri bilinmektedir. Birlikte karar alma, toplam kalite anlayışının yaygınlaşması, demokratik işletmecilik, bireysel sorumluluk gibi değerler, katılımın farklı düzeylerde yaşama geçirilmesini zorunlu kılmaktadır. Yönetişim yaklaşımı da bu tür düşüncelerin yaygınlaşması sonucunda anlam kazanmış ve güçlenmiştir (Çukurçayır ve Eroğlu, 2012: 216).

Bu kavramı ilk defa Dünya bankası, 1989 tarihli raporunda kullanmıştır. Daha sonra, Ekonomik İşbirliği ve Kalkınma Örgütü (Organization for Economic Cooperation and Development-OECD) raporlarında, 1992 yılında Rio de Janeiro'da yapılan Birleşmiş Milletler (BM) Çevre ve Kalkınma Konferansında, 1994 tarihli Kahire Nüfus ve Kalkınma Konferansında, 1995'te gerçekleşen Kopenhag Sosyal Gelişme Konferansında, 1996'da İstanbul'da düzenlenen BM İkinci İnsan Yerleşmeleri HABITAT II Konferansında, 2000 New York Binyıl (Millenium) Zirvesinde ve 2002 tarihli Johannesburg Dünya Sürdürülebilir Kalkınma Zirvesinde (Rio+10) kavram daha net hale gelmiştir. 1992 Rio Konferansının en temel belgesi olan Gündem 21 belgesi "küresel ortaklık" kavramını gündeme getirmiş, bu kavramla birlikte geleneksel yönetim anlayışı, yerini çok aktörlü yönetim olarak yönetişime bırakmıştır. Bu yeni anlayış çerçevesinde hükümetler, yerel yönetimler, iş çevresi, işçiler ve işçi sendikaları, hükümet dışı kuruluşlar, bilim insanları, kadınlar, çocuklar, gençler ve yerli halk ortaklar olarak görülmeye başlanarak, sorunların çözümünde ve kararların alınmasında toplumun tüm kesimlerinin sorumluluk alması gerektiği vurgulanmıştır (DPT, 2007: 2) 


\subsection{Yönetişim Kavramının Tanımı ve Kapsamı}

Yönetişim sözcüğünün İngilizce orijinali olan "governance”in Yunanca'da yönlendirmek, yol göstermek, yönetmek ve hükmetmek anlamlarına gelen "kybernan" sözcüğünden geldiği görülmektedir. Bu kelime, Latince "gubernare" ve eski Franssızca'da "governer", Arapça'da ise en yakın karşılığının "al-hakimiya" olduğu görülmektedir (Demirci, 2012: 139).Yönetişim; birlikte yönetmek demektir. Kamuda yönetişim, yönetim ve karar alma süreçlerinin tüm paydaşların işbirliği ve katılımı ile yapılmakta olduğunu, yöneticilerin uzlaşmacı, saydam, hesap verebilir, etkin ve sorumlu bir yönetim anlayışı içerisinde davrandıklarını ifade etmektedir. Yani, yönetim sadece seçimler aracılığ kesim tarafindan değil; (Sivil Toplum Kuruluşları) STK'lar, odalar, meslek grupları, özel sektör kuruluşları, üniversiteler gibi çeşitli grupları da süreçlere dahil ederek gerçekleşmektedir. Yönetişim kavramı içerisinde, yönetenlerin aldıkları kararları halka açık bir şekilde almalarını, tüm ilgili paydaşları sürece katmalarını ve bilgiye dayalı, uzlaşmacı bir yönetim anlayışı sergilemeleri beklenmektedir. (TESEV, 2008: 17).

Hem küresel hem de yerel düzeyde ortaya çıkan yönetişim kavramı, TODAİE'nin kamu yönetimi sözlügünde "bir toplumsal politik sistemdeki ilgili bütün aktörlerin ortak çabalarıyla elde edilen sonuçların oluşturduğu yapı ya da düzen" olarak ifade edilmektedir (TODAİE, 1998: 274). Okçu'ya göre (Okçu, 2012: 11) Yönetişim kavramı Türkçede, yönetim kelimesine "işteşlik" ekinin eklenmesiyle birlikte ortaya çıkmıştır. Yönetişim kelimesi yönetme işinin sadece bir kişi ya da grup tarafindan değil de mevcut olan diğer aktörlerin de katılımıyla gerçekleştirilmesi anlamına gelmektedir. Eryılmaz'a göre (Eryılmaz,2013: 60) Yönetişim, son otuz yıl içerisinde popüler hale gelmiştir. Ve "yönetim" kavramının alternatifi olarak literatürde ve günlük hayatta yaygın olarak kullanılmaktadır. Yönetişim, toplum ve devlet ilişkilerinde karşılıklı etkileşime dayalı yeni bir yönetim tarzını ifade etmektedir. Fidan, yönetişimi kapsamlı biçimde (Fidan, 2011 6-7), "örgütsel amaçların mükemmel olarak gerçekleştirilmesi için güçlendirilmiş kişilerin, ortak çıkarları kişisel çıkarlarının önüne alarak davrandığı, iletişim ve etkin bilgi paylaşımı, karşılıklı güven ve şeffaflı̆̆ benimsemiş, müşterek karar verebilen, duygusal zekâs1 yüksek, empatik, proaktif ve sinerjik davranarak gerçekleştirilen örgütsel etkinlikler" şeklinde tanımlamıştır. $\mathrm{Bu}$ bağlamda Yönetişimin, bir nevi orkestrayı anımsattığını, Yönetişimciyi de orkestra şefine benzeterek; Yönetişimci olarak orkestra şefinin görevini etkin olarak yapabilmesi, takımında bulunan her bir enstrümana kulak vermesi, değerlendirmesi ve tepki vermesine bağlamaktadır.

Yönetişim hakkındaki teorik çalışmaların büyük bir kısmı iktidarın kullanım biçimini veya egemenlik yapısını düşünmekten ve irdelemekten ziyade genel olarak toplumu yönetmenin en etkin ve verimli yollarını aramaya yönelik olmaktadır. Bu kapsamda yönetişim, iktidar gücünün sınırlarına ve hükümet dışı örgütlerin rolüne ilişkin yeni bir bakış açısına yönelik talebi yansıtmaktadır. Dünya ekonomisinde çok uluslu şirketlerin artan etkisi, üretim metotlarındaki değişim, uluslararası ticaretin giderek genişlemesi, bilgi ve iletişim teknolojilerindeki ilerleme, sermaye ve finans pazarlarının yeniden düzenlenmesi gibi faktörlerin, söz konusu kavramın ortaya çıkıp yaygınlaşmasında belirleyici bir etkide bulunmaktadır (Yüksel, 2000: 147).

Yönetişim, farlı disiplinlerde farklı anlamlarda kullanıldı̆̆ gibi kamu yönetimi disiplininde de farklı anlamlarda kullanılmaktadır. Kamu yönetiminde yönetişim kavramının aldığı anlamlar şu şekildedir (Demirci, 2013: 29-30): 
- Yönetişim, siyasal kurumların yapısıdır.

- Yönetişim, bürokratik devletten üçüncü taraf yönetimine geçiştir.

- Yönetişim, yönetime piyasa temelli yaklaşımlardır.

- Yönetişim, sosyal sermaye, sivil toplum ve yüksek düzeyde vatandaş katılımının gelişmesidir.

- Yönetişim, risk alan yetkili kamu girişimcilerinin çalışmalarıdır.

- Yönetişim, İngiltere'de Tony Blair'in “Üçüncü yol” yaklaşımı anlamında kullanılmaktadır.

- Yönetişim, Yeni Kamu İşletmeciliğidir.

- Yönetişim, Kamu sektörünün performansıdır.

- Yönetişim, çeşitli yetki alanları arasında işbirliği ve ağbağ yönetimidir.

- Yönetişim, küreselleşme ve rasyonelleştirmedir.

- Yönetişim, şirketlere nezaret etme, şeffaflık ve muhasebe standartlarıdır.

Yönetişim kavramının en belirgin özelliği kamusal kararların alınmasında ve uygulanmasında merkezi yönetimin egemen ve belirleyici güç olmaktan çıkaran yerel, bölgesel, ulusal ve uluslararası pek çok aktörün sürece dahil edilmesi ve diyalog ortamının oluşturulması, devletin iktidarını başka güçlerle paylaşması, ayrıca sivil toplum örgütlerinin karar alma süreçlerinde rollerinin artmasıdır. Bu kapsamda yönetişim geleneksel yönetimden farklı olarak sivil toplum kuruluşlarını da içermesi nedeniyle daha geniş kapsamlıdır, Hak talep eden ve yönetilen vatandaş yerine, bir takım sorumluluklar ve ödevler üstlenen aktif vatandaşa vurgu yapmaktadır (DPT, 2007b: 5).

Yönetişim, toplumsal çıarları dengelemekte ve toplumsal aktörlerin ve dizgelerin kendilerine çekidüzen vermelerini sağlayacak biçimde olanakları ve sınırlılıkları ortaya çıkarmaktadır. Bu çerçevede yönetişimin; katılım, hukuk devleti, şeffaflık, duyarlık, oydaşmacılık, eşitlik, etkinlik ve verimlilik, sorumluluk ve stratejik vizyon gibi unsurları bünyesinde barındırdığı söylenebilmektedir (Özer, 2006: 66).

Yönetişim kavramı, sistemsel, siyasal ve yönetimsel olmak üzere üç boyutuyla ele alınabilir. Sistemsel olarak yönetişim, siyasal iktidarın kurumsallığını ve klasik yapısını tasvir eden hükümetten daha geniş bir kavram olarak tanımlanmaktadır. Siyasal boyutta yönetişim, siyasal iktidarın meşruiyetini ve demokratik yönetimini ifade etmesinin yanı sıra, vatandaşların seçimler dışında da yönetime katılımını anlatır. Yönetimsel boyutta kastedilen, kamu hizmetlerinde nitelik ve şeffaflığı sağlama açısından pozitif yönde bir değişim potansiyeli yaratmaktır (Göymen, 2000: 6-7).

Yönetişim, kamu yönetiminin alanını devletin faaliyet alanının sınırlandırılmasına yönelik bazı çabaları ele alarak ve yönetsel sürece özel sektör ve sivil toplum örgütlerini de dâhil ederek genişletmektedir (Eryılmaz, 1999: 28-29). Ekonomik kalkınmada ekonomik, sosyal ve politik öncelikler üzerinde bir fikir sağlanmasını gerekli kılar. Yetki devirleri aracılığıyla katılımcılığı sağlar. Seçilmiş görevlilerin fonksiyonlarını azaltır. Seçilmiş görevliler için hedef ve sorumluluk belirlemeyi temel bir amaç haline getirir. Katılımcılık, saydamlık ve demokratik katılımcılığı yönetsel süreçte etkin kılar (Özer, 2005: 314-315). 


\subsection{Yönetișimin Temel İlkeleri ve Özellikleri}

Günümüzde artık yaygın bir şekilde yönetişim, ülkelerin kaynaklarının ekonomik ve toplumsal gelişme için nasıl kullanılacağını belirleyen gelenekler ve kurumsal yapılar olarak görülmeye başlanmıştır. Kararların nasıl alındığı, gücün nasıl kullanıldığı ve ülke insanlarının bu sürece nasıl katıldığı konusundaki uygulamalar ise yönetişimin kalitesini belirlemektedir. $\mathrm{Bu}$ süreçte yönetişimin amacı, hem toplumsal sorunlarla hem de çağdaş toplumların karmaşıklığını, dinamikliğini ve çeşitliliğini yaratan olgularla baş edebilmek olmaktadır. Karmaşıklık, toplumsal dinamikler ve çeşitlilik, yeni oluşan toplumsal alt sistemler nedeniyle devletlerin içsel egemenliğinin azalmasına yol açabilmektedir (Özer, 2006: 66).

Bu bağlamda yönetişim; üniversiteler, Sivil Toplum Kuruluşları vb., özel ve kamu sektörü kurum ve kuruluşları gibi yerel aktörleri harekete geçirerek onları eşgüdümlü biçimde ortak akılda buluşturarak olanaklar sağlamaya çalışmaktadır. $\mathrm{Bu}$ çerçevede yönetişimin; katılımcılık, etkililik ve etkinlik, verimlik, şeffaflık, hukuk devleti, eşitlik, sorumluluk, sürdürülebilirlik vb. unsurları bünyesinde barındırdığı söylenebilir.

Şaylan'a göre (Şaylan, 2000: 20) bu unsurlardan yola çıkarak yönetimde, içerisinde müşteri tatmini, toplam kalite yönetimi vb. yaklaşımlarla uyumlu bir biçimde bütünleşebilmektedir. Pazarın belirleyiciliği içinde çatışmacı değil dayanışmacı bir toplum öngörmekte. Yani toplumun bölüşümdeki paylarını maksimuma çıkarmak için yarışan değil, dayanışma içinde olmaları gereken, farklı fonksiyonları bir araya getiren olgu olarak görmektedir.

$\mathrm{Bu}$ kapsamda Yönetişimin temel ilkeleri, tutarlılık (öngörülebilirlik), sorumluluk, hesap verebilirlik, adillik, saydamlık, katılımcılık, etkinlik, hukuka bağlılık, yerindelik ve ölçülülük olarak sıralanabilir (TESEV, 2008: 18). Ekonomik, sosyal ve politik öncelikler: Yönetişim katılımcılık, saydamlık ve hesap verebilirlik ilkeleri üçgeni içinde korunmakta, bu üçgen sayesinde, ekonomik kalkınmada, ekonomik, sosyal ve politik öncelikler üzerinde bir konsensüs sonucunda ortaya çıkabilmektedir(Özer, 2006: 66).

- Stratejik vizyon: Kamu yönetiminde liderler iyi yönetişim ve kalkınma hususunda etkin bir perspektife sahip olmalı ve gelişmeye yönelik gerekli unsurları belirleyerek bunları sağlamalıdırlar(Özer, 2006: 81). Yönetişim seçilmiş görevlilerin fonksiyonlarını mevcut olandan daha az önemli göstermektedir. Tartışmalarda bu bakış açısından hareket edildiğinde, ağsal ilişkilerin gelişimi ve kamu kaynakları ile özel kaynakların bir araya getirilmesi önem kazanmaktadır (Özer, 2006: 66).

- Tutarlılık: Verilen kararların gerek birbirleriyle, gerekse zaman içerisinde uyumlu olması devletin yapacağı düzenlemelerin öngörülebilir olmasını ve vatandaşların güven duyacakları bir ortamda ileriye yönelik gelişim yatırımlarını gerçekleştirmelerini sağlar (TESEV, 2008: 18).

- Katılımcılık ve Yerindenlik: Karar alma süreçlerinin hazırlıktan uygulamaya ve oradan da izlemeye kadar olan aşamalarında bireyden başlayarak sivil toplumun ve halkın etkin biçimde sürece dahil olmasını ifade eder. Kamu sektörünün aldığ1 kararların katılımcı bir anlayış ile alınması, kararların o karardan etkilenecekleri kapsayacak düzeyde verilmesi kararların uygulanma olasılığını artırır(TESEV, 2008: 19).

- Etkinlik ve oransallık: Yönetimin aldığ kararların herkese eşit ve eş zamanlı uygulanması ve elde edilmesi beklenen sonuçlar ile gerek kullanılacak kaynaklar, 
gerekse olumsuz etkilenecek kesimlere olan etkileri arasında makul bir ilişki olması anlamina gelir (TESEV, 2008: 19).

- Yönetimde Açıklık (Şeffaflık): Açıklıktan kast edilen kamu kurum ve kuruluşlarının elinde bulunan belgelerin vatandaş erişimine açık bir tarzda faaliyet göstermesidir. Özer'e göre (Özer, 2006: 79) Yönetimde şeffaflık serbest bilgi akışının sağlanması ile mümkün olabilmektedir. Bu ise; usullerin, kurumların ve bilgilerin, ihtiyacı olanlar için kolaylıkla erişilebilir olması ile gerçekleşebilecektir.

- Bürokratik şartlar: Demokrasi bağlamında gelişen sorunların çözümünde siyasal sorumluluk ve bürokratik denetim fonksiyonlarının oldukça önemli olduğu söylenmektedir. Örgüt yapılarının bu süreçte demokratik yönetişimi kendilerinin üretmesi gerekmektedir (Özer, 2006: 67).

- Adillik: Kamu sektörünün aldığı kararlarda toplumun her hangi bir kesimini kayırıcı uygulamalar yapmaması ve vatandaşın tabi olduğu kuralların açık ve net şekilde ortaya konarak herkese aynı şekilde uygulanması vatandaşların devlete güven duymalarını sağlar(TESEV, 2008: 18).

- Hukuka bağlılık: Yönetimin hukuk kuralları içinde kalarak, objektif bilgiye dayalı karar vermesi ve kararların hukuk yolu ile denetlenmesini ifade eder(TESEV, 2008: 19).

- Cevap verebilirlik: Kurumların ve usullerin tüm vatandaşlara hizmet etme gayreti içinde olması gerekmektedir. $\mathrm{Bu}$ ilke, vatandaşların yönetimde/hükümette bulunanlarca dinleneceklerini bilmeleri anlamına gelmektedir. Duyarlı yöneticinin, cevap vermeye hazır, sempatik, sorunlara duyarlı aynı zamanda halkın ihtiyaç ve isteklerini anlayabilen ve uygulayabilen bir yapıda olması gerekmektedir (Özer, 2006: 80).

\subsection{Yönetişim Türleri:}

Yönetişim kavramıyla kastedilenin ne olduğunu tam olarak ifade edebilmek için kavrama bazı sıfat ve bir takım özellikler yüklenmiştir. Bu nedenle yönetişim kavramının tek başına değil de çeşitli sıfatlarla kullanıldığı görülmektedir: Çok düzlemli yönetişim (multi-level governance), çok ölçekli yönetişim (multi-scalar governance), küresel yönetişim (global governance), iyi yönetişim (good governance), kurumsal yönetişim (corporate governance) gibi (Demirci, 2012: 144). Literatürde genel olarak yönetişim; bir ülkenin ekonomik faaliyetlerini ve diğer ekonomilerle olan ilişkilerini etkileyen süreçleri içeren, eşitlik, yoksulluk ve yaşam kalitesi üzerinde etkileri bulunan iktisadi yönetişim, politika oluşturmadaki karar süreçlerini ortaya koyan siyasi yönetişim ve politika uygulama sistemini içeren idari yönetişim şeklinde üçe ayrılmaktadır. Ayrıca, yönetişim için; kamu kuruluşları, özel sektör ve sivil toplum kuruluşları işbirliğinde, yönetime katılma anlamında ve ideolojik temelleri aynı ancak mekansal farklılıklara göre katılımın boyutlarında ortaya çıkabilecek değiş̧iklikler dikkate alınarak, mekan ölçeğine göre ulus-üstü, ulusal ve yerel ölçek olmak üzere üçlü bir sınıflandırma yapılabilmektedir (Özer, 2006: 74). 


\subsubsection{Küresel Yönetişim:}

Küreselleşme sürecinde sorunlar küresel boyut kazanarak karmaşık hale gelmektedir. Salgın hastalıklar, küresel ısınma sorunu vb. herkesi ilgilendiren sorunlarla baş edebilmek için uluslararası işbirliğine ve katılıma ihtiyaç olmaktadır. Böyle bir ortamda küresel yönetişim küresel iktidar ilişkilerinde devletlerin yansıra, devlet diş1 aktörlerin (uluslararası ve bölgesel örgütler, çok uluslu şirketler, finans piyasaları vs.) önemine vurgu yapar (Demirci, 2013: 144). Küresel sorunlara küresel çözümler arama 1990'lı yıllarla beraber yoğunlaşmıştır. Hiyerarşik yapılar yerlerini çok aktörlü işlevsel yapılara bırakmaktadır. Özellikle küresel sivil toplum örgütleri, küreselleşen sorunlar karşısında ortak çözümler aramaya yönelmektedirler. Ulus devletler, uluslararası kurumlar, AB, BM, diğer bölgesel ve küresel örgütler ile sivil toplum örgütleri ve yerel siyaset aktörlerinin işbirliği yaptıkları yeni bir düzen, yeni bir anlayış öne çıkmaktadır (Gündoğan, 2010: 50). Bu düzende küresel yönetişim, ulus devletlerden oluşan bir dünya sistemindeki hükümet etme biçimine alternatif olarak önerilen yeni yönetme stratejisini ortaya koymuştur. Hükümet ve toplum arasındaki etkileşimin yeni biçimlerini ifade etmek üzere kullanılan yönetişim kavramının, hükümet ve toplum arasındaki sınırda, kamusal ve özel sektörlerin geleneksel olmayan yeni yönetme yollarında somutlaştığı iddia edilmiştir. Bunun yanında küresel yönetişim, ulus devletlerin yönetme kapasitelerinin ilerisine giderek, merkezi bir otoritenin yokluğunu ima etmiş ve hükümetler ile kar amacı gütmeyen sivil toplum kuruluşları arasındaki işbirliğini formüle etmeye çalışmıştır (Özer, 2006: 75). Küresel yönetişim anlayışının amacı, yakın zamanda kurulan küresel ve uluslararası organizasyonları ön plana çıkararak yeni bir siyasal sistemin öğelerini ortaya koymaktır (Bayramoğlu, 2014: 126).

\subsubsection{Kamu yönetişimi:}

Kamu sektörünün ve özel sektörün, bireylerin ve sivil toplum kuruluşlarının, diğer meslek örgütlerinin yönetime katılımları biçiminde tanımlanabilmektedir. $\mathrm{Bu}$ durumda da çatışan çıkarların uzlaşıcı bir ortamda harmanlandığı bir süreçtir. Dünyada yaşanan büyük değişime paralel olarak, devletin içine girdiği yeniden yapılanma süreci ve bu süreci, belirleyen çok yönlü, karmaşık etkileşimler kamu yönetimi alanında yeni yaklaşımları gerekli kılmaktadır. Ancak bu yaklaşımlar genel olarak kamu sektörünün temel görevleri arasındaki farklılıklardan kaynaklanmaktadır. Buna göre; mal ve hizmetler arasındaki bölüşüm, gelir dağılımı ve bunu korumaya dönük çalışmalar, başta özel sektör olmak üzere kamu sektöründe de düzenlemeler yapmak, ekonomik kuralları yönetmek çabaları, yönetişim yaklaşımlarını ortaya çıkarmıştır. Bunlardan kamu yönetişimi; ulusal, bölgesel, yerel, siyasal, sosyal gruplardan, baskı ve çıkar gruplarından, sosyal kuruluşlardan özel ve ticari organizasyonlardan oluşan ağların yönetimini içermektedir (Özer, 2006: 7778). 


\subsection{3. İyi Yönetișim:}

Yönetişim ve iyi yönetişim kavramları literatürde kimi zaman birlikte ve birbirinin yerine geçecek şekilde kullanılmaktadır. Ancak, bu kavramların ortak yanları olduğu gibi farklılıkları da vardır. $\mathrm{Bu}$ bağlamda iyi yönetişim yönetişimin eylemsel durumudur diyebiliriz. Yönetişimin ilkelerinin uygulanması aşaması iyi yönetişim boyutudur.

İyi yönetişim, demokratik bir yönetimin kurulması için gerekli tüm ilkeleri içeren yeni bir anlayıştır. Bu ilkeler; katılımcılık, saydamlık, hesap verebilirlik, etkinlik, tutarlılık, adillik ve hukuka bağlılık olarak sıralanabilir (TESEV, 2008: 3).

İyi yönetişim, Demirci'ye göre (2012: 145), uluslararası kurumların yönetişime ilişkin normatif görüşlerini ilan etmelerine ilişkin bir kavramdır. AB'den Dünya Bankası'na kadar birçok uluslararası kurum, daha iyi bir dünya için temennilerini ifade etmek maksadıyla yönetişimin sorunlu yönlerine hitap eden hesap verme sorumluluğu, demokrasi, aleniyet, hukukun üstünlüğü gibi birçok ilkeden oluşan listeleri iyi yönetişim adı altında kullanmaktadır.

Kavram; vatandaşların güvenliğinin sağlandığı, hukukun üstünlüğünün gerçekleştiği ve yarg1 bağımsızlığının var olduğu hukuk devletini, kamu harcamalarının adil ve doğru bir şekilde yöneten kamu kuruluşlarını, siyasal liderlerin eylemlerinden dolayı halka hesap verebildiği veya halkın onlardan hesap sorabildiği, bütün vatandaşların gerekli bilgiye kolayca ulaşabildiği saydam yönetimi ve insan haklarının asgari gereklerini içermektedir (Özer, 2006: 79).

İyi yönetişim toplumsal yaşamda dört düzeyde gerçekleşebilir (TESEV, 2008: 8):

- Kamu düzeyinde

- Özel sektör düzeyinde

- STK'lar düzeyinde

- Bireysel düzeyde.

Kamu yönetimi düzeyinde iyi yönetişim, devlet organlarının ve kamu hizmeti veren kuruluşların katılımcılığı özendirmesi ile başlar, yaklaşımlarının tutarlılık, şeffaflık ve hesap verebilirliğinden geçer ve kararlarla uygulamaların adil ve etkin olmasıyla sonuçlanır (TESEV, 2008: 8).

İkinci olarak, özel sektör düzeyinde iyi yönetişim, iç içe geçmiş iki kanaldan gerçekleşebilir. Bir yandan şirketlerin kendileri kurumsal yönetişimi uygularlar ve bu doğrultuda kendi yönetim yapılarında şeffaflığı, hesap verebilirliği, katılımcı yönetim tarzını, etkinliği ve verimliliği yaşama geçirirler. Diğer yandan da toplumsal projelere kaynak ayırarak, yönetici ve çalışanlarının zamanlarının belirli bir bölümünü, bu projeler yoluyla STK'ların etkinliklerine ayırmaya teşvik ederler (TESEV, 2008: 8).

Üçüncü olarak; STK'ların kendi içlerinde iyi yönetişimi esas almaları, "Toplam Kalite Yönetimi” ilkelerinin uygulanması, bu çerçevede etkin yönetimin yaşama geçirilmesi, yöneticilerin seçiminde belirli çevrelerin ya da hatır gönül ilişkilerinin rol oynamasındansa işinin ehlini seçme anlayışının egemen olması, genel anlamda toplumda iyi yönetişim ilkelerinin yerleşmesinde çok önemli bir rol oynayacaktır. Ülkemizde de, Yerel Gündem 21 aracılığı ile kamu sektörünün karar mekanizmalarına katılımını sağlayan STK'lar öncü roller üstlenmiştir (TESEV, 2008: 9). 
Dördüncü olarak, iyi yönetişim ilkelerinin yaşama geçmesinde bireyler önemli bir sorumluluk taşımaktalar. Kişisel düzeyde, her insan bir yandan tüketici, bir yandan yurttaş, bir yandan da bir bireydir. Bu sorumlulukları yerine getirirken tutarlılık, adillik, saydamlık, hesap verebilirlik, katılımcılık ve etkinlik gibi iyi yönetişim ilkelerine sahip çıkarak, STK'lar da dahil olmak üzere her kurumun gelişmesine ve toplumsal refahımızın artmasına katkıda bulunacaktır (TESEV, 2008: 9).

\section{Alan Çalışması}

\subsection{Araştırmanın Amacı:}

Bu çalışmanın amacı Aydın ili özelinde vergi dairesi; müdürleri, müdür yardımcıları, gelir uzmanları ve avukatlarının vergi dairelerinden yönetişim perspektifinde beklentilerini ortaya koyarak değerlendirmektir.

\subsection{Araştırmanın Yöntemi:}

Araştırmada anket yöntemi uygulanmıştır. Aydın İli içerisinde 18 Vergi dairesi bulunmaktadır. Aydın Vergi Dairesi Başkanlığı 196, ilçe Vergi Dairesi ve Mal Müdürlüklerinde 386 personel görev yapmaktadır. Araştırmada, ortalama 580 ana kütlenin 160 örneklemine uygulama yapılmıştır. Yönetişim İlkeleri kapsamında yöneltilen sorulara verilen cevaplar değerlendirilmiştir. Verilerin değerlendirilmesi SPSS 16 programına aktarılmıştır. $\mathrm{Bu}$ programdan yararlanılarak üçlü lineer kullanılarak değerlendirme yapılmıştır.

\subsection{Araştırmanın Güvenilirlik Analizi ve Bulguları:}

$\mathrm{n}($ örneklem büyüklüğ̈̈ $)=\frac{\mathrm{N} \cdot \mathrm{t}^{2} \cdot p \cdot q}{d^{2} \cdot(N-1)+t^{2} \cdot p \cdot q}$

$\mathrm{N}$ : Hedef kitledeki birey sayıs1

n: Örnekleme alınacak birey sayısı

p: İncelenen olayın görülüşs sıklığı (gerçekleşme olasılı̆̆ı)

q: İncelenen olayın görülmeyiş sıklığı (gerçekleşmeme olasıllı̆̆ı)

t: Belirli bir anlamlılık düzeyinde, $\mathrm{t}$ tablosuna göre bulunan teorik değer

d: Olayın görülüşs sıklığına göre kabul edilen örnekleme hatasıdır

Formüle göre, belirlenen örneklem sayısının $\% 95$ güven düzeyinde ve $\% 5$ göz yumulabilen hata payı dikkate alınarak evreni temsil ettiği düşünülmektedir.

Örneklem say1s1 $=\frac{580 \cdot(1,96)^{2} \cdot(0,38) \cdot(0,62)}{(0,05)^{2} \cdot(580-1)+(1,96)^{2} \cdot(0,5) \cdot(0,5)}=217$ kişi 
Örneklem büyüklüğü 217 kişi olarak belirlenmiş olup, anket soru formlarındaki eksik, hatalı, yanlış bilgiler ve boş bırakılanlar dikkate alındığında 57 anket soru formu değerlendirilmeye alınmamış ve 160 anket analize tabi tutulmuştur.

Güvenilirlik analizi ölçmede kullanılan testlerin, anketlerin özelliklerini, güvenilirliklerini, yer alan soruların birbirleri ile olan tutarlıl1lığını ve kullanılan ölçeğin sorunu ne derece de yansıttığını değerlendirmek üzere geliştirilmiş bir yöntemdir.

Güvenilirlik analizinde amaç ölçmenin hatalardan arındırılmış olmasıdır. Ölçeğin Cronbach Alpha güvenilirlik katsayısı $0.00 \leq \alpha<0.40$ güvenilir değil, $0.40 \leq \alpha<0.60$ düşük derecede güvenilir, $0.60 \leq \alpha<0.90$ oldukça güvenilir ve $0.90 \leq \alpha<1.00$ yüksek derecede güvenilirdir.

Tablo 1. Modelin Cronbach's alpha değeri

\begin{tabular}{|l|l|}
\hline Cronbach's Alpha & Soru say1s1 \\
\hline 0,754 & 25 \\
\hline
\end{tabular}

Tablo ‘da görüldüğü gibi modelin cronbach's alpha değerinin $0.60 \leq \alpha<0.90$ olması durumu modelin oldukça güvenilir olduğunu göstermektedir.

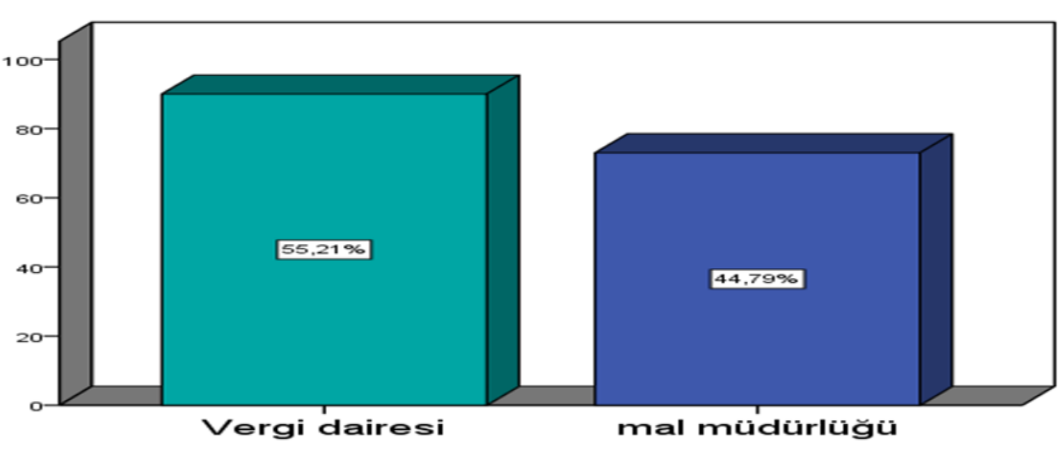

Sekil 1. Kurum Analizi

Şekil 1'de Kurumda çalışan personelin birimlere göre dağılımı verilmiştir. Çalışanların \%55.21'ini Vergi Dairesi personeli \%44.79'unu Mal Müdürlüğü personeli oluşturmaktadır. 


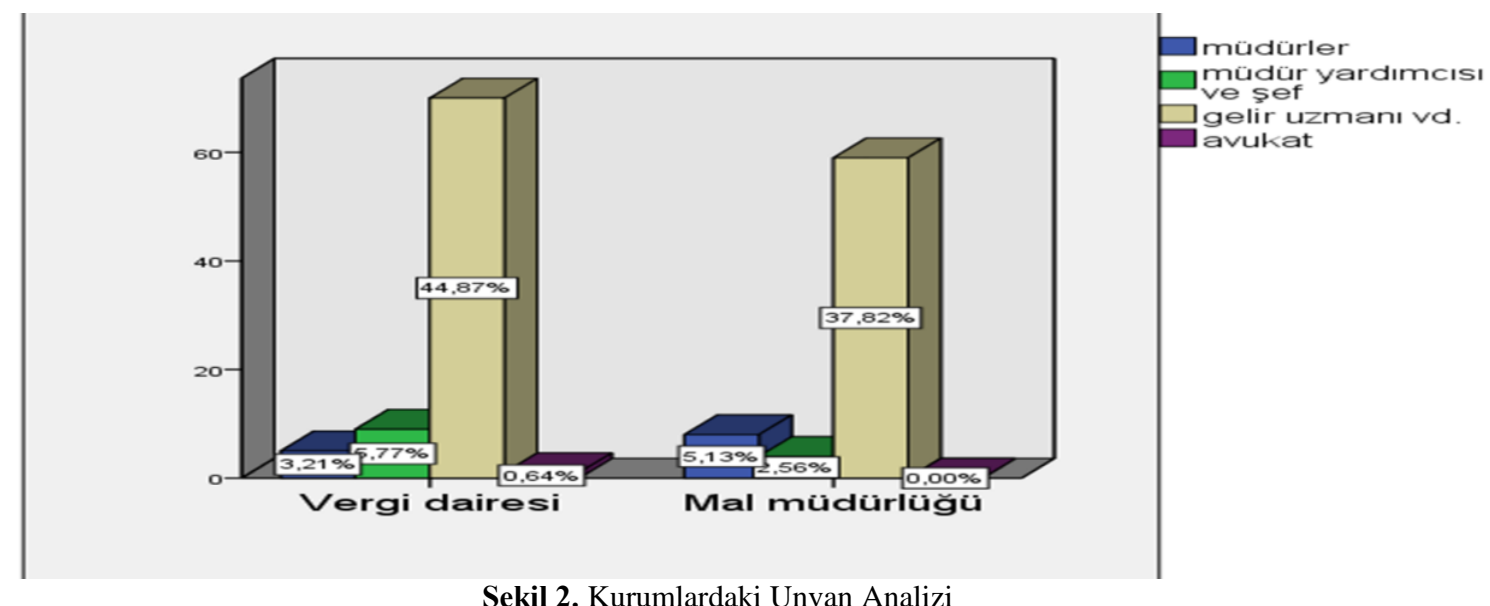

Sekil 2. Kurumlardaki Unvan Analizi

Şekil 2'de Vergi Dairesi Personellerinin \%3.21'ni müdürler, \%5.77'ni müdür yardımcıları ve şefler, \%44.87’ni gelir uzmanları \%0.64'ünü avukatlar oluşturmaktadır. Mal Müdürlügün de ise Personelerin \%5. 13'ünü müdürler \%2.56'nı müdür yardımcıları ve şefler, \%37.82'ni gelir uzmanları ve \%0.01'ni avukatlar oluşturmaktadır.

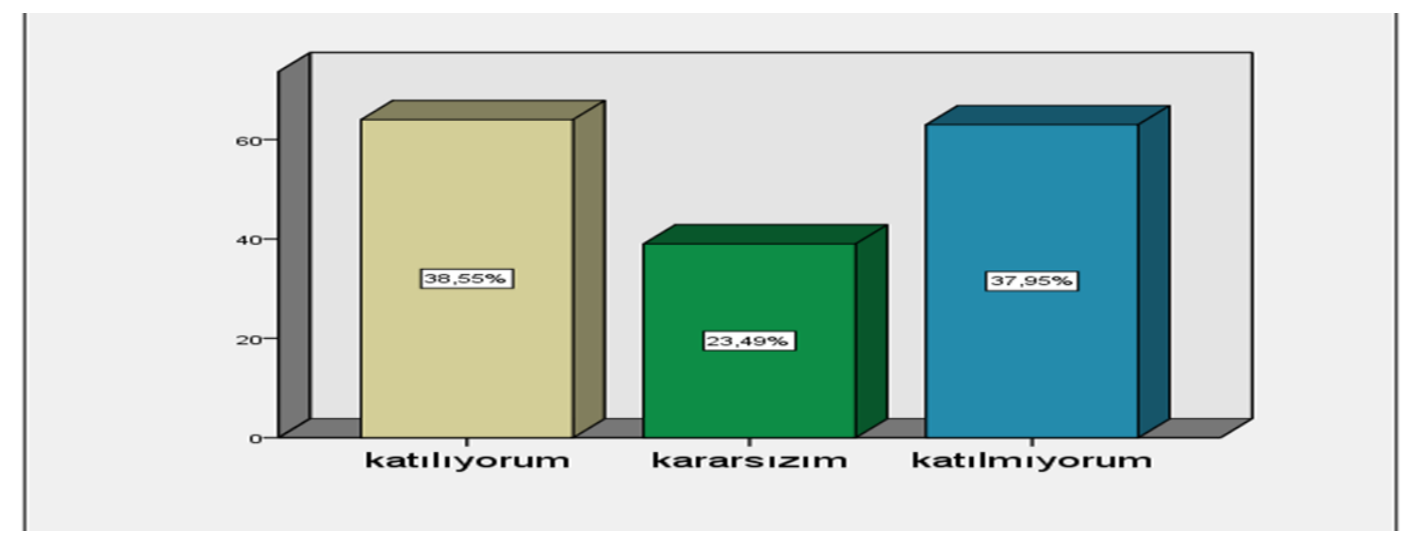

Şekil 3. Kamu Gelirleri Tamamen Kamusal Hizmetler İçin Harcanmaktadır

Şekil 3'de ankere katılanlar verdiği vatandaştan zorunlu olarak alınan en öneli kamu gelirleri içinde yer alan verginin, tam anlamıyla kamusal himetlerin finansmanında kullanılmadığ kanaatini belirtmiştir. 


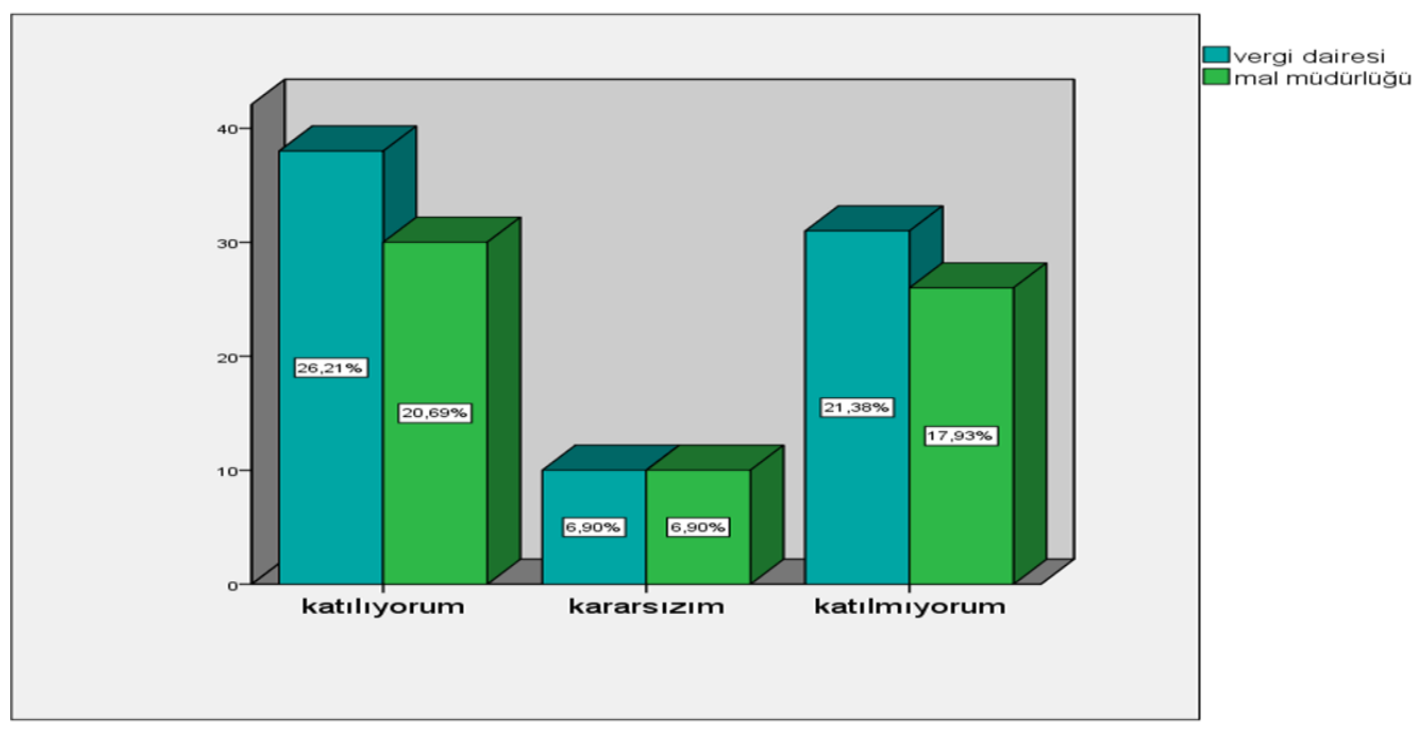

Şekil 4. Zamanında Tahsil Edilen Vergilerin Devlete Daha Fazla Katki Sağladığının Önemi Konusunda Bilgilendiriliyoruz

Verginin zamanında tahsil edilmesi, hem vergi tahsidarı devletin kamu hizmetlerinin sağlıklı biçimde yürütlmesi açısından hemde ödeyici vatandaşın cezai yaptırımlara maruz kalmaması açısından önemlidir. Bu hususta Şekil 4'te de görüldüğü gibi ankete katılanlan Vergi dairesi ve Mal Müdürlüğü personellerinin \%46.90’1 vergilerin zamanında tahsil edilmesi konusunda bilgilendirildiklerini beyan ederken \%39.31'i bilgilendirilmediklerini beyan etmiştir. Kararsız kalanların oranı ise \%13.8 olarak belirlenmiştir. Burdan hareketle kurum personellerinin verginin zamanında tahsili konusunda yeterince bilgilendirilmedikleri görülmektedir.

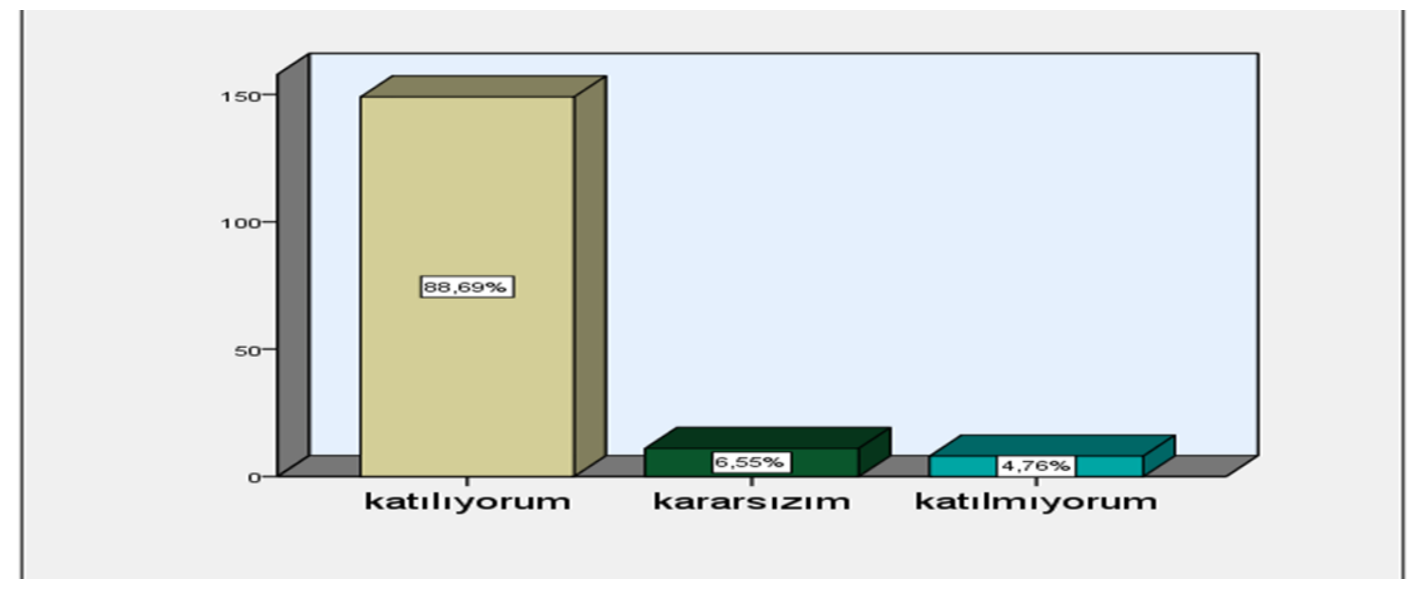

Şekil 5. Mükelleflere Tatmin Edici Açıklama Yapıyoruz

Vergi mevzuatının yeterince açık olmaması nedeniyle Vergi dairesine gelen vatandaş, çalışanların bilgisine ihtiyaç duymaktadır. Bu nedenle kendileriyle bir müşteri gibi ilgilenilmesi ve mükellefiyetleri konusunda tatmin edici açıklmalar yapılması gerekmektedir. 
Ankete katılanlarının \%88.69'unun mükelleflere tatminleri oranında gereken bilgileri aktardıkları beyan edilmiştir.

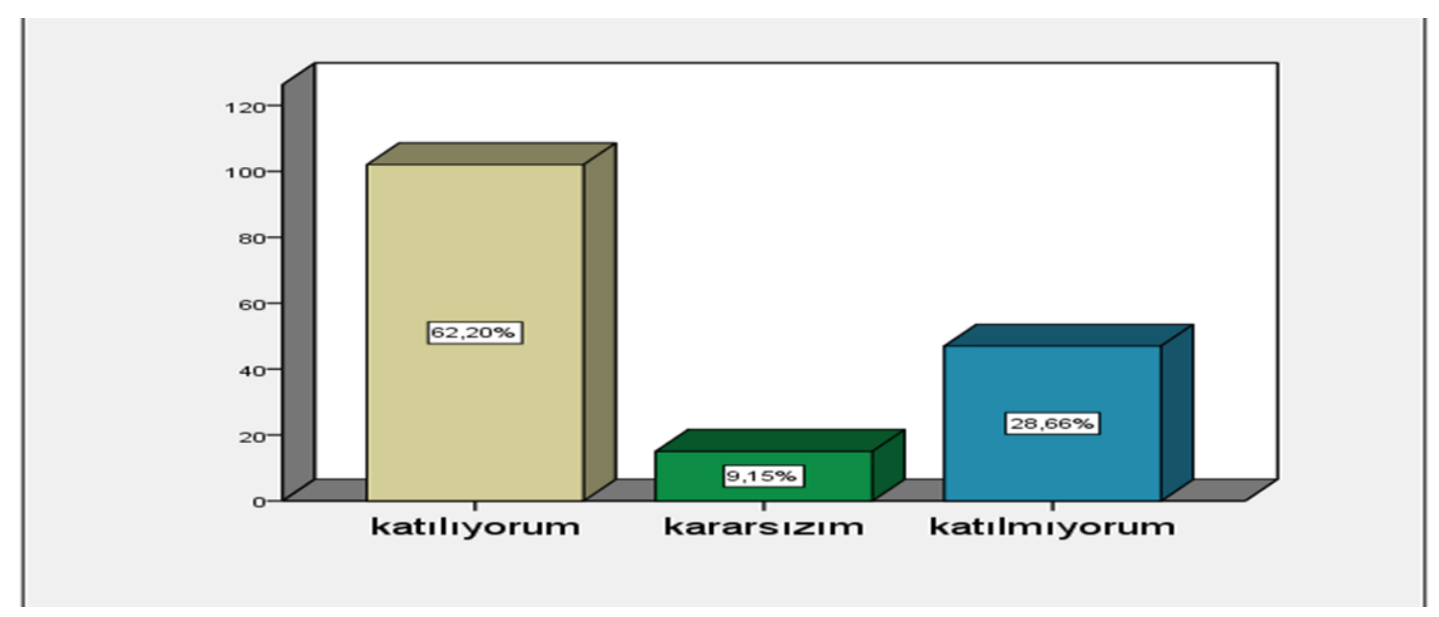

Şekil 6. Mükelleflere Gereken Prosedürleri Takip Ettiriyoruz

Ankete katılanların \%62.20'si mükelleflere vergiyle ile ilgili işlemlerini gerçekleştirirken mevzuat gereği izlemeleri gereken yol ve yöntemleri yeterli şekilde takip ettirdiklerini söylemişlerdir.

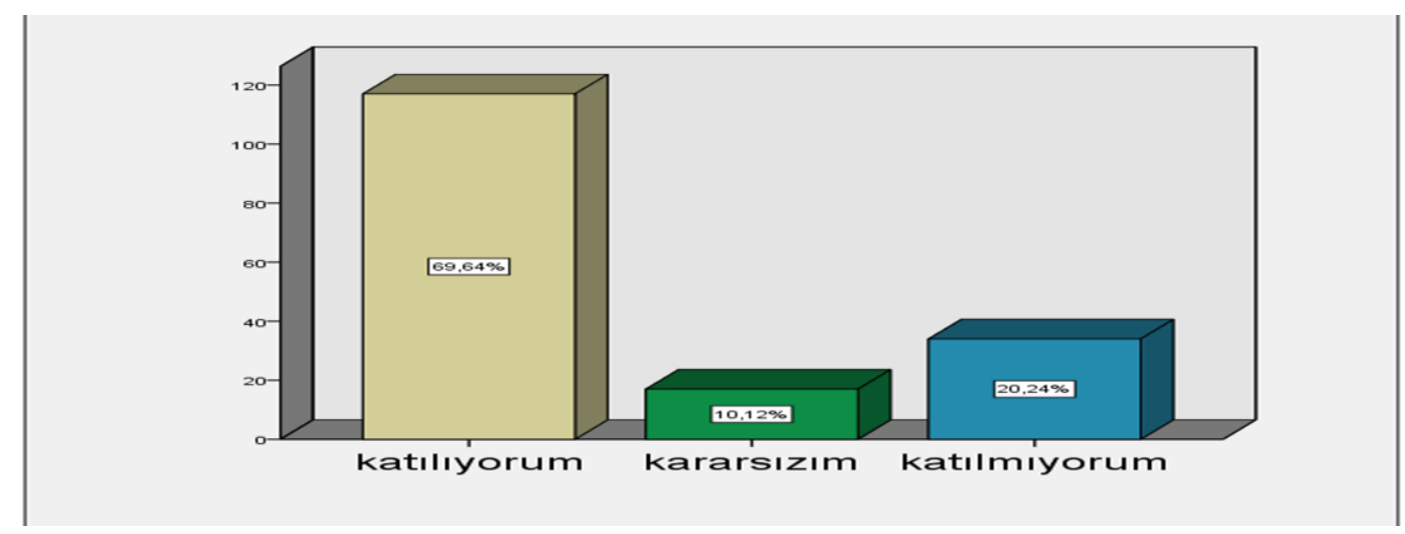

Şekil 7. Vergisel İşlemlerdeki Uygulamalar Hukuka Olan Güveni Zedeliyor

Şekil 7'de ankete katılanların \%69.64'ü vergisel işlemlerdeki uygulamaların Vergiyle ilgili sürekli gündeme getirilen af yasaları ve vergi cezalarının caydırıcılıktan yoksun olması gibi etmenlerin vergisini zamanında ödeyen vatandaşın bir yandan hukuka olan güvenini zedelediğini bir yandan da vegi ödevinden kaçınmasına neden olduğunu belirtmiştir. 


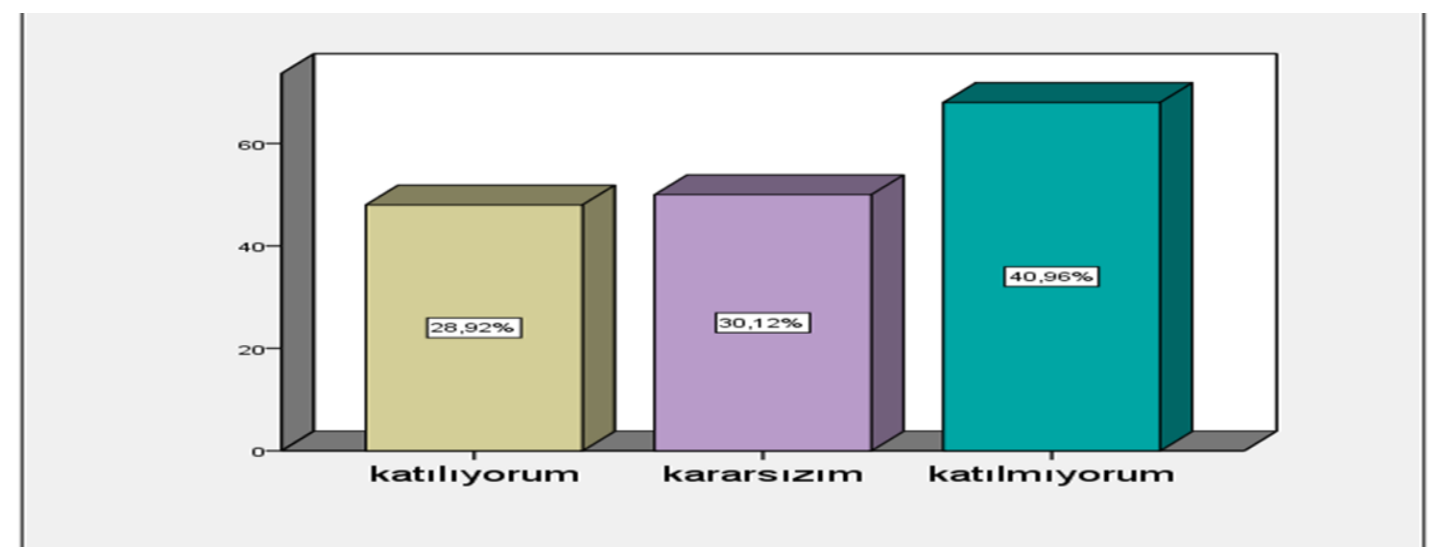

Şekil 8. Vergilerin Etkin Şekilde Kullanıldığını Düşünüyorum

Vergi, toplumsal refağı sağlayan en önemli kamu hizmeti araçlarından birisidir. Vatandaş odaklı Yeni Kamu Yönetimi anlayışı çerçevesinde toplumsal büyüme ve kalkınmanın gerçekleştirilebilmesi için kamu gelirlerinin etkin ve etkili bir şekilde yürütülesi büyük öneme sahiptir. Ancak, bu konuda ankete katılanların \%30.12'si kararsız kalımıştır. Katılanların, \%28.92'si vergilerin etkin şekilde kullanıldı̆̆ı beyan ederken, \%40.96'sı vergilerin etkin şekilde kullanılmadığını düşünmektedir.

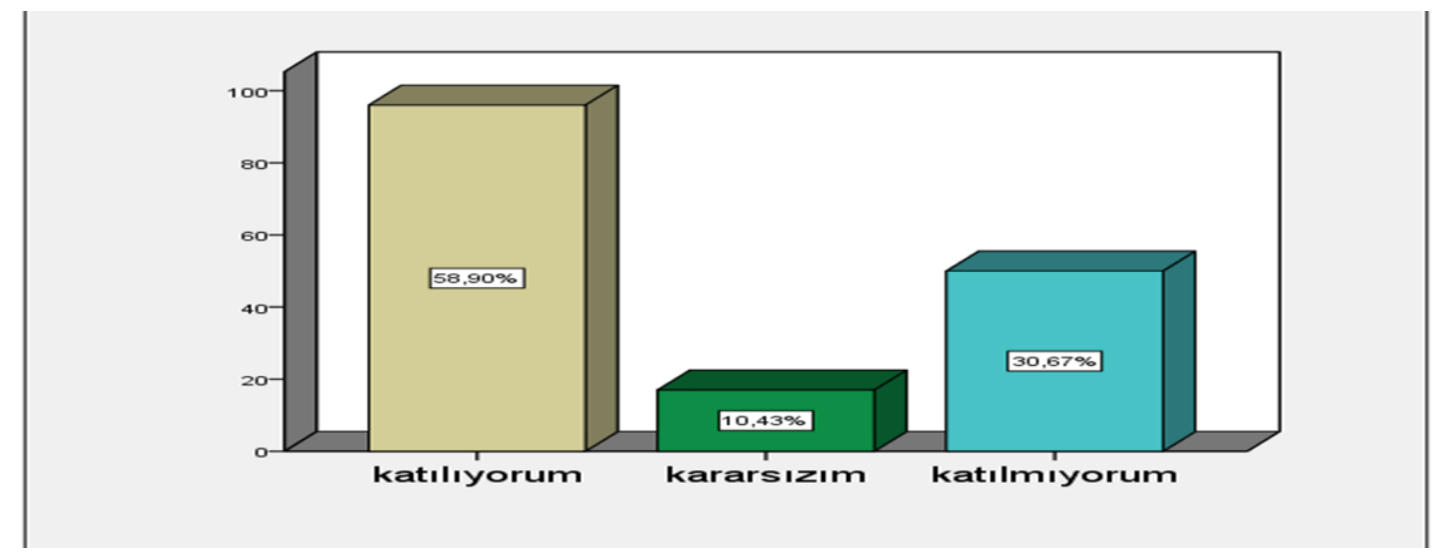

Şekil 9. Vergilere Gönüllü Uyumun Olmadığını Düşünüyorum

5345 Sayılı Kanun kapsamında Gelir İdaresi Başkanlığı (GİB)'nın Teşkilat ve Görevleri Hakkında Kanunun amacı; gelir politikasını adalet ve tarafsızlık içinde uygulamak; vergi ve diğer gelirleri en az maliyetle toplamak; mükelleflerin vergiye gönüllü uyumunu sağlamak; mükellef haklarını gözeterek yüksek kalitede hizmet sunmak suretiyle yükümlülüklerini kolayca yerine getirmeleri için gerekli tedbirleri almak; saydamlık, hesap verebilirlik, katılımcılık, verimlilik, etkililik ilkelerini gerçekleştirmektir. Ankete katılanların \%58.90'nının belirttiği üzere vatandaşın vergiyi gönüllü olarak vermediği ve verginin zorlamaya dayılı bir ödev olmasından cezai yaptırımlardan çekindiği için ödediği düşünülmektedir. Her ne kadar vergi zorla alınan bir kamu geliri olsa da vergi konusunda başarı elde edebilmenin yolu; vatandaşa vergide gönüllülük esasını kazandırmaktır. 


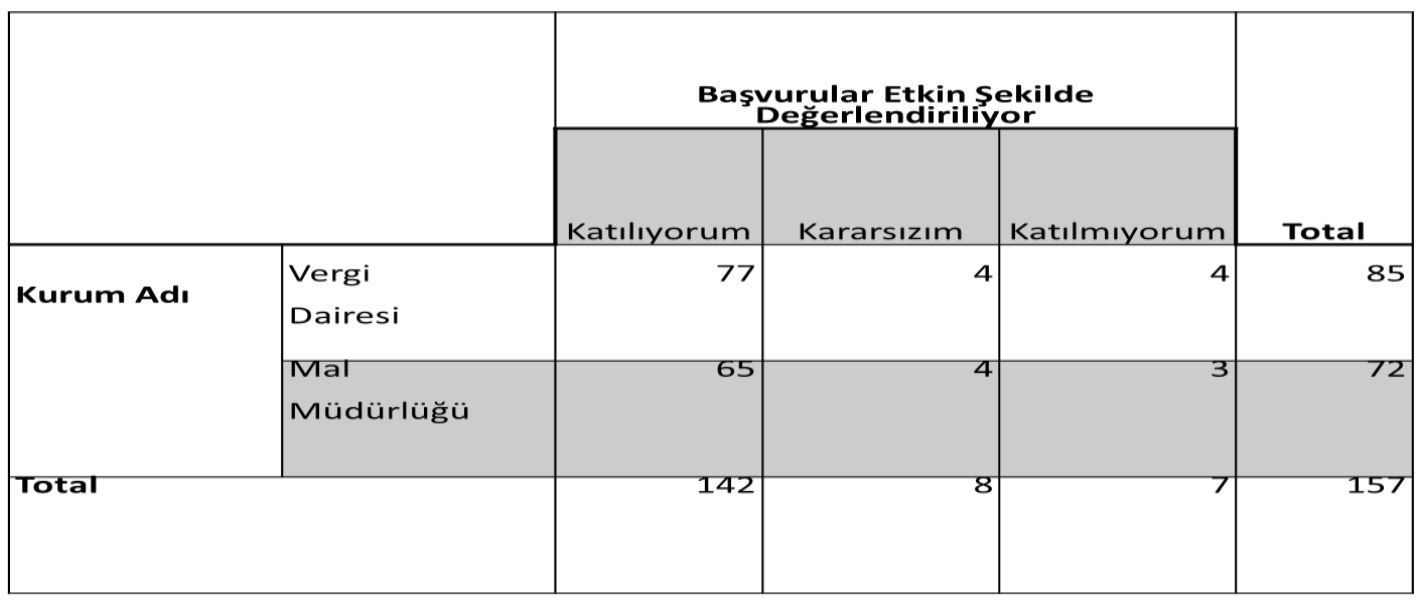

Şekil 10: Başvurular Etkin Şekilde Değerlendiriliyor

Vatandaş memnuniyetinin sağlanabilmesi için Vergi Dairesine yapılan başvuruların etkin bir şekilde değerlendirilmesi önemlidir. Bu konuda; ankete katılıp bu soruyu cevaplayan toplam 157 çalışanın 142 başvuruların etkin şekilde değerlendirildiğini söylemiştir.

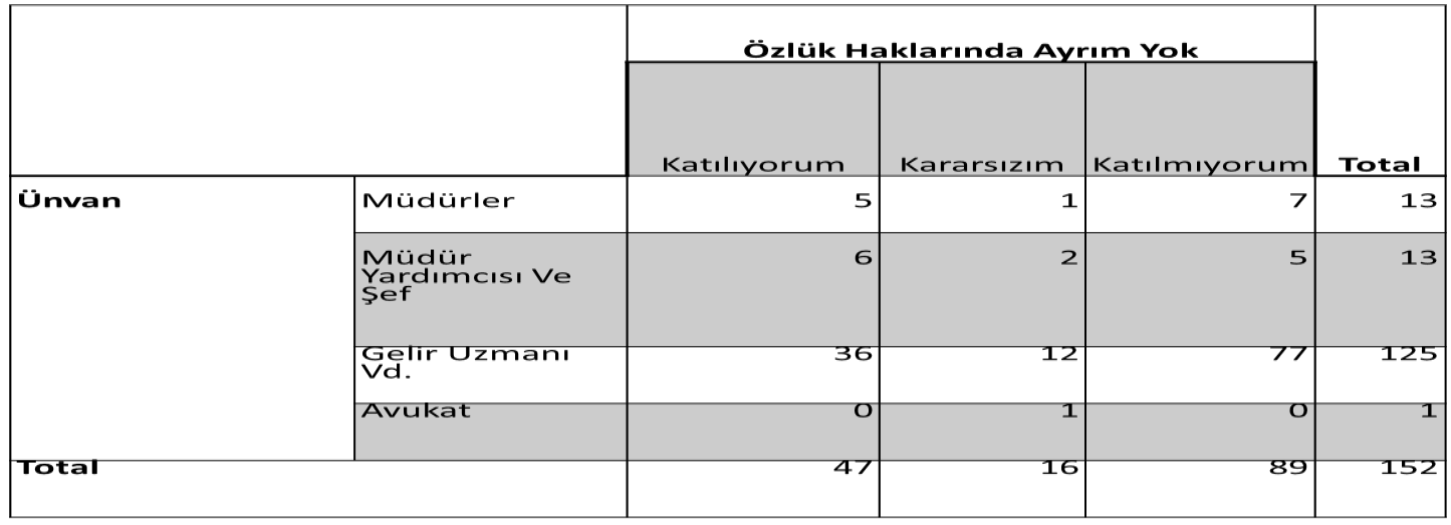

Şekil 11. Aynı Statüdeki Meslektaşlarımla Özlük Haklarımda Ayrım Olmadığını Düşünüyorum

Sağlıklı bir kamu hizmetinin yerine getirilmesi için kurum içerisinde çalışan personelin işbirliği içerisinde hareket etmesi ortak akılın hakim kılınması ve uyumun sağlanması gerekmektedir. Şekil 11'de ankete katılan 13 müdürün 5'i özlük haklarında ayrım olmadığını düşünürken 7'si ayrım olduğunu düşünmektedir. 1'i ise kararsız kalmıştır. Aynı soru 13 müdür yardımcılarına yöneltildiğinde, 6'sı ayrım olmadığını 5'i ise ayrım olduğunu beyan etmiştir. 2 müdür yardımcısı ise bu konuda kararsız kalmışırı. 125 gelir uzmanı ve yardımcılarının 36'sı özlük haklarında ayrım olmadığını düşünürken, 77'si ise ayrım olduğunu söylemiştir. 12 gelir uzmanı ise kararsız kalmıştır. Ankete katılan 1 kurum avukatı da kararsız kalmıştır. 


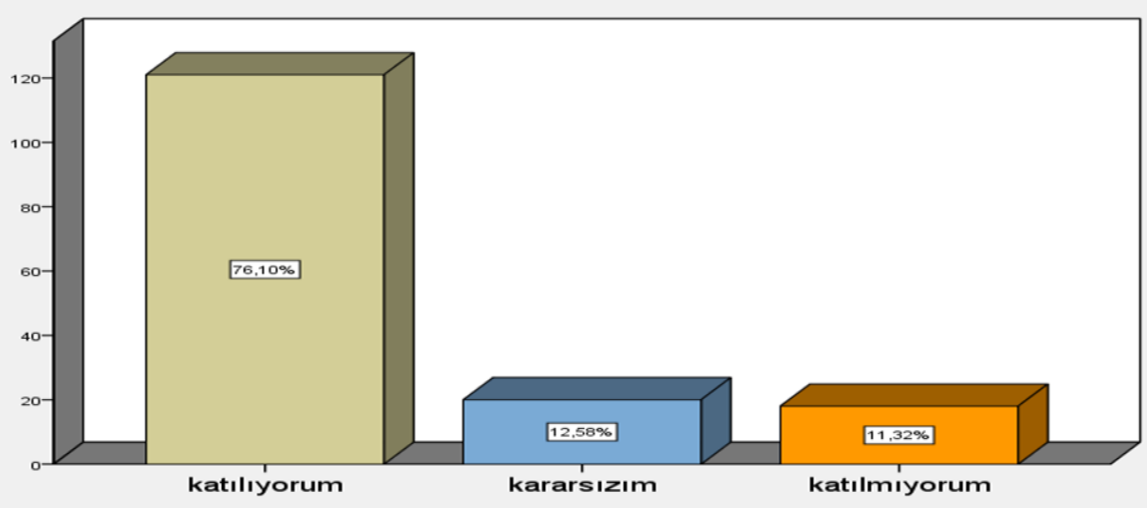

Şekil 12. Farklı Gelir Grupları Arasında Vergi Adaletini Bozucu Uygulamaların Olduğunu Düşünüyorum

Şekil 12'de ankete katılanların \%76.10'nu farklı gelir grupları arasında vergi adaletini bozucu dolaylı vergi uygulaması gibi uygulamaların olduğunu düşünmektedir. Vergi adaletinin sağlanabilmesi için vatandaşın kazancına göre (az kazanandan az, çok kazanandan çok) vergi alınması gerekir. Ancak, vergi sisteminde dolaylı vergilere ağırlık verilmesi gibi uygulamalar vergi adaletini zedelemektedir.

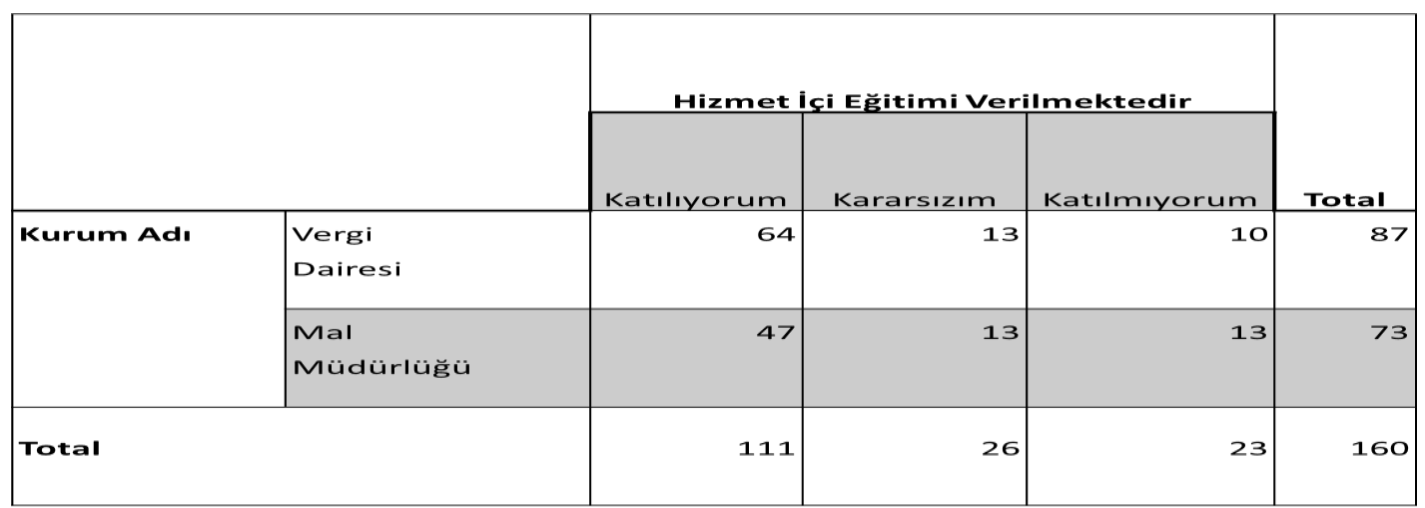

Şekil 13. Kurumumuzda Hizmet İçi Eğitim Verilmektedir

Ankete katılan kişilere Vergi Haftası dışında vergi ile ilgili yeterli hizmet içi eğitim verilip verilmediği sorulmuştur. Bu soru ile Vergi Haftası dışında diğer zamanlarda da idarenin, verginin önemine ilişkin eğitimleri yeteri düzeyde verip vermediği araştırılmaya çalışılmıştır. Şekil 13'te de görüleceği üzere ankete katılan 160 kişinin 111'i idarenin vergi haftası dışında da eğitim verdiği belirtmiştir. 


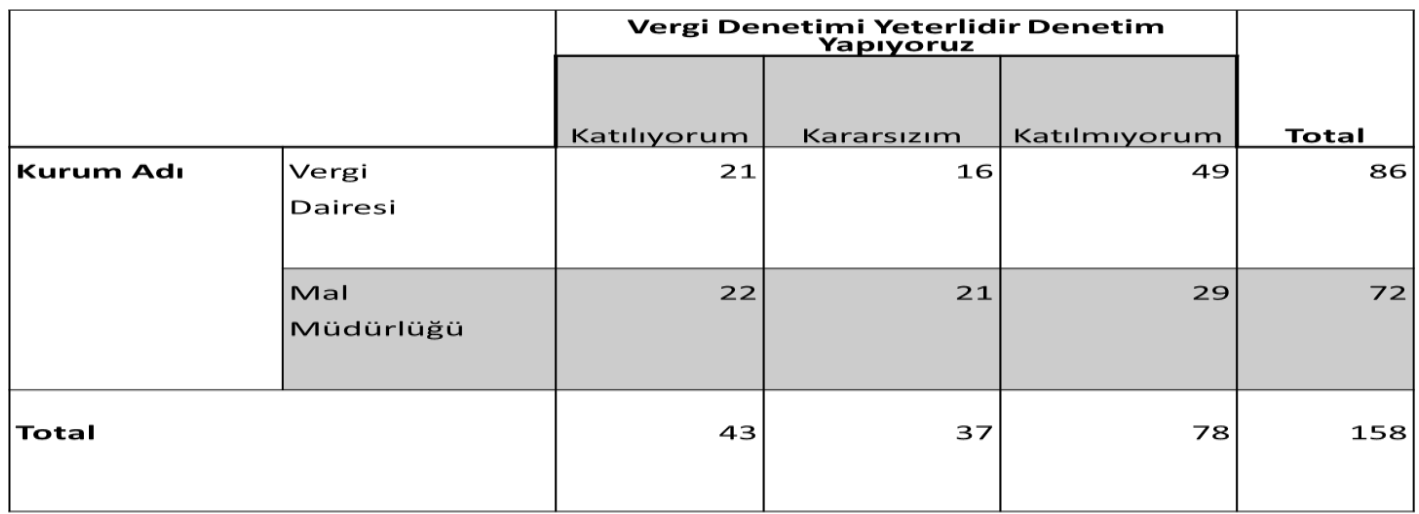

Şekil 14. Mükellefler Üzerinde Vergi Denetimi Yeterlidir. Biz De İmkanlarımız Ölçüsünde Denetim Yapıyoruz

Vergi sistemlerini başarılı kılan etmenlerin başında etkin bir vergi denetiminin sağlanması gelmektedir. Mükelleflerin beyanı üzerine alınan vergilerin gerçeğe uygun biçimde beyan edilip edilmediğinin Vergi daireleri tarafindan denetlenmesi hem keyfiliğin önüne geçilerek kamuoyu nezdinde güveni tahsis etmek hemde vergi kayıplarının önüne geçerek verginin gelir dağılımı üzerinde olumlu etkisini oluşturmaktır. Şekil 14'de görüldüğü üzere mükelleflerin üzerindeki vergi denetimlerinin yeterli olduğunu düşünenlerin sayısı ankete katılan 158 kişi içerisinden 43 kişidir. 37 kararsız kalan kişilerin de sayısı dikkat çekmektedir. 78 kişi de vergi denetimlerinin yeterli olduğunu düşünmemektedir.

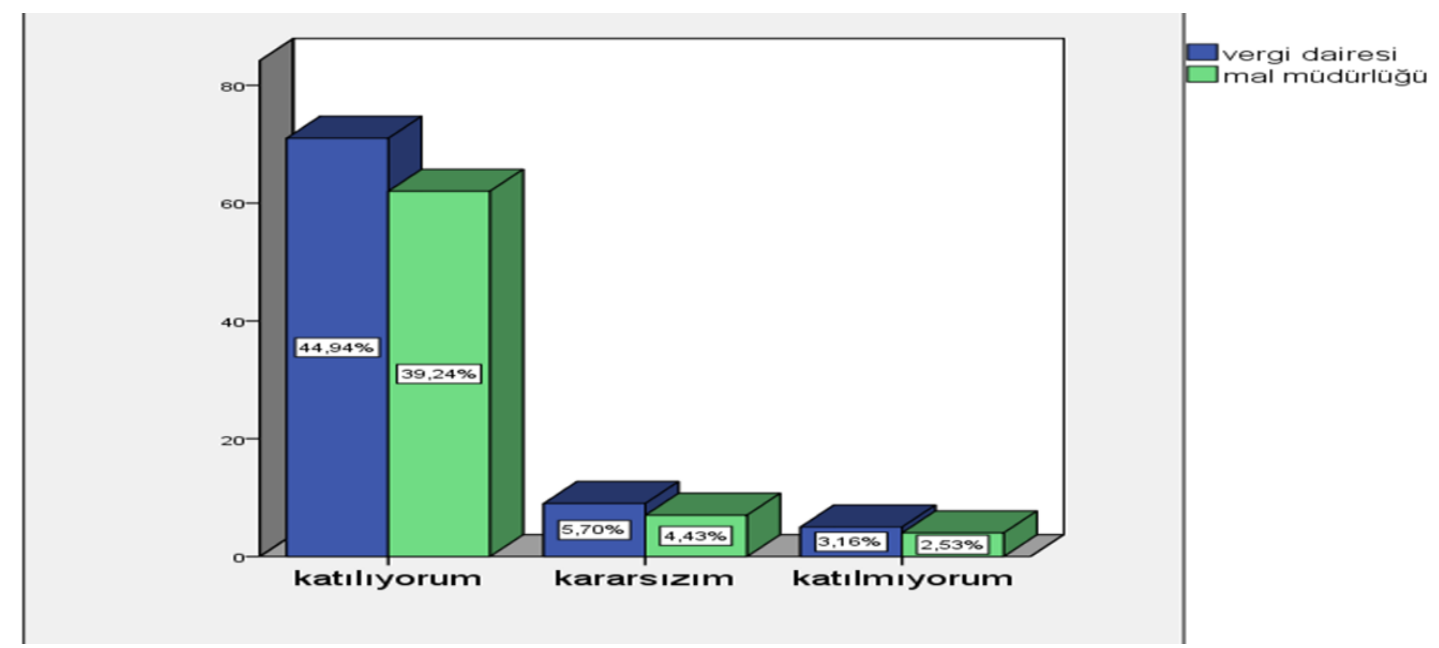

Şekil 15. Vergisel İşlemlerin Elektronik Ortamda Yapılması Yükümüzü Hafifletiyor

Yönetişimci yaklaşımla Kamu Yönetimi içerisinde hızlı bir şekilde yer edinen, geleneksel uygulamaların yerine iletişim teknolojilerin kullanımını ifade eden e-devlet uygulamaları; Kurumlar arasında işbirliğinin sağlanması, devlet yönetimine vatandaş katılımının gerçekleştirilmesi, şeffaflık ve hesapverilebilirliğin tesis edilmesi için faydalıdır. Bu soru ile vergisel işlemlerin e-devlet uygulaması ile yapılması çalışanların iş yükünü azaltıp azaltmadığı araştırılmaya çalışımıştır. Vergi Dairesi ve Mal Müdürlüğü içerisinden ankete katılanların \%84.18'i elektronik ortamın iş yüklerini hafiflettiğini belirtmiştir. 


\begin{tabular}{|c|c|c|c|c|c|}
\hline & \multicolumn{3}{|c|}{ Bilgi Edinme Bașvuru Yolları } & \multirow[b]{2}{*}{ Total } \\
\hline & & BIMER & $\begin{array}{c}\text { Bilgi Edinme } \\
\text { Dilekçesi }\end{array}$ & $\begin{array}{l}\text { Üst Makama } \\
\text { Başvuru }\end{array}$ & \\
\hline \multirow[t]{2}{*}{ Kurum Adı } & Vergi Dairesi & 16 & 21 & 4 & 41 \\
\hline & Mal Müdürlüğü & 8 & 10 & 8 & 26 \\
\hline \multicolumn{2}{|l|}{ Total } & 24 & 31 & 12 & 67 \\
\hline
\end{tabular}

Tablo 16. Birimimize Yapılan Başvuru Yolları

$\mathrm{Bu}$ soru ile mükelleflerin vergi dairesine, vergisel işlemlerle ilgili başvuru yaparken etkin olarak hangi başvuru yollarının kullanıldığını araştırmaktır. Tabloda da görüldüğü üzere Vergi Dairesine başvuru yolunu ağılıklı olarak BİMER ve dilekçe oluşturmaktayken, Mal Müdürlüğünde Dilekçe, BIMER ve Üst Makama Başvuru yolları birbirine yakın sayılarda yer tutmaktadir.

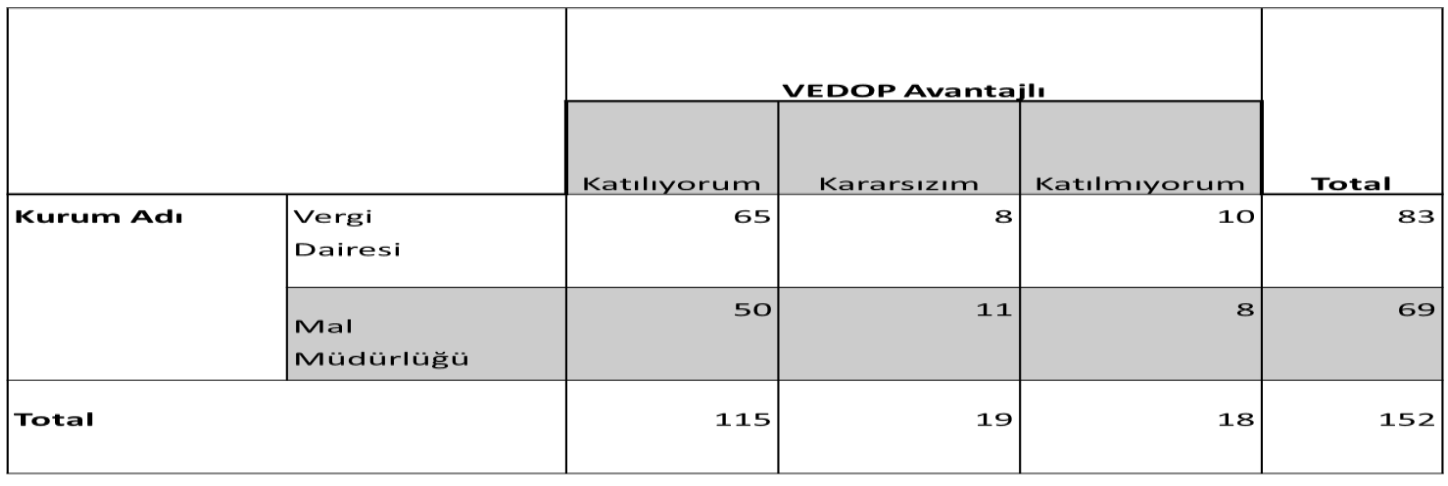

Şekil 17. Vergi Daireleri Otomasyon Projesi Avantajlıdır

Vergi Dairesi Otomasyon Projesinin (VEDOP) amacı: Vergi beyannamelerinin elektronik ortam üzerinden alınması, kayıtdışı ekonominin kayıt altına alınması ve verginin tabana yayılmasını sağlamaktır. Ankete katılan 152 kişiden 19 kişi bu soru karşısında kararsızlığını belirtmiş̧lerdir. 19 kişi VEDOP'un avandajlı olmadığını ifade ederken; 115 kişi avantajlı olduğunu belirtmiştir. 


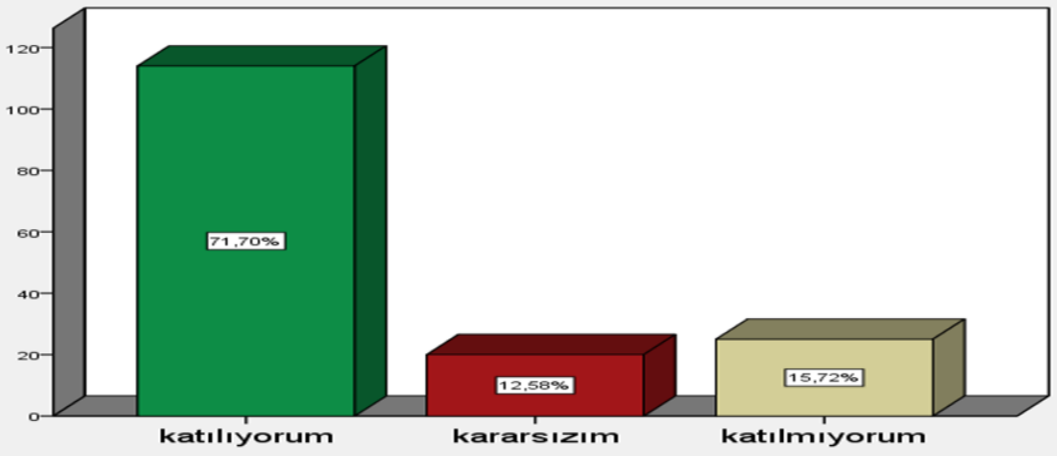

Şekil 18. Vergi Mevzuatının Sık Sık Değiştirilmesi Mükelleflere İşini Zorlaştırmaktadır

Ankete katılanların \%71.70'i vergi mevzuatında yapılan değiş̧iklerin mükellefin işini zorlaştırdığ kanaatinde bulunmuştur.

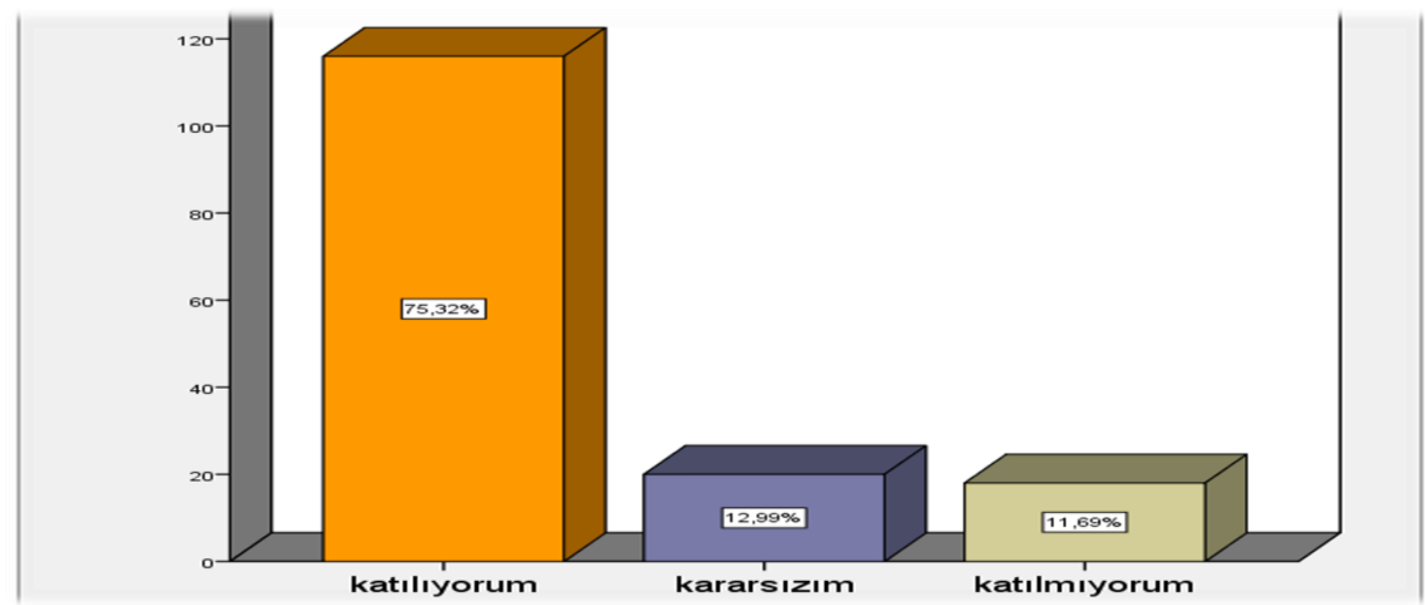

Şekil 19. Mükellef Bilgileri Doğru Ve Ulaşımı Kolay Bir Şekilde Tutulmaktadır

Mükelleflerin vergisel yükümlülüklerinin temelin tutulan siciller oluşturmaktadır. Sicillerin, yanlış tutulması mükellefin mağdur olmasına neden olabilmektedir. Bu nedenle hem geriye yönelik mükellef bilgisine kolay ve hızlı erişim konusunda hemde mükelleflerin mağdur edilmemesi için kayıtların doğru tutulması önemlidir. Ankete katılanların \%12.99'u kararsız kalırken, \%11.69'u bilgilerin doğru ve ulaşımı kolay bir şekilde tutulduğu görüşüne katılmazken; \%75.32'si katıldığı yönünde görüşbildirmişlerdir. 


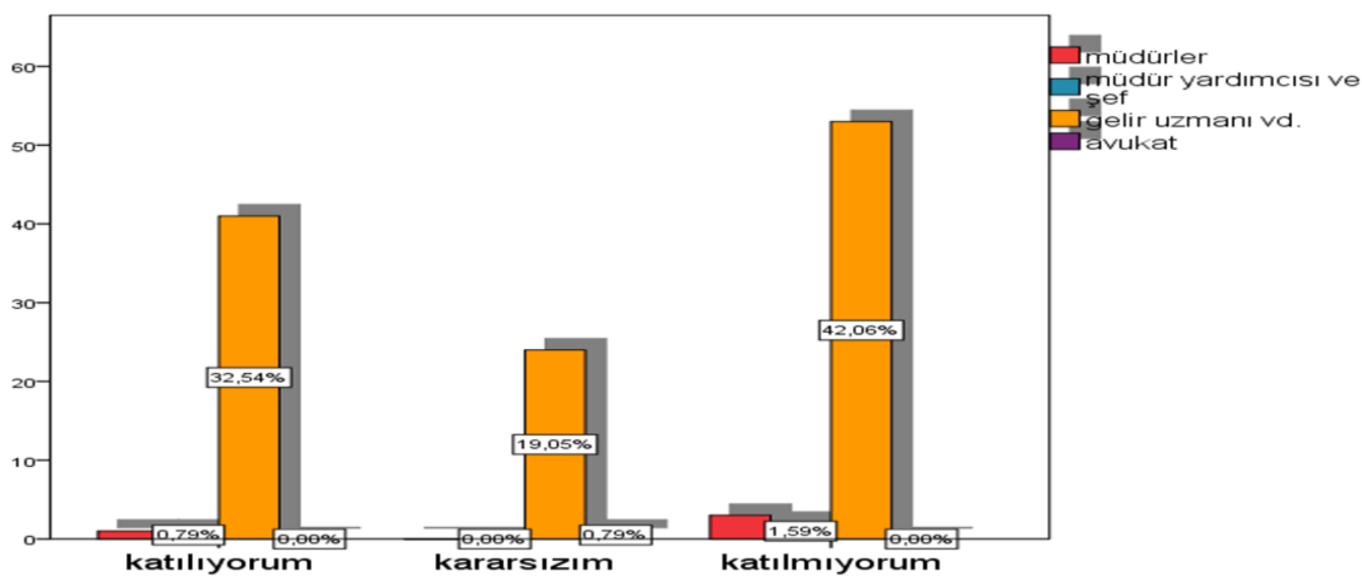

Şekil 20. Yöneticilerimiz Birimimizdeki Bazı Uygulamalar İçin Görüşümüzü Alırlar

Hem yöneticilerin hemde yönetilenlerin katılımının sağlandığı, kurum içi demokrasinin gerçekleştirildiği bir yapı; kamu hizmetlerinin sağlanması husunda daha başarılı olacaktır. Ankete katılan gelir müdürlerin; \% 1.59'u üstlerinin görüşlerini almadığını ifade ederken, \%0.79'u görüşlerinin alındığını söylemişlerdir. Gelir uzmanlarının \%42.06'sı görüşlerinin alınmadığını belirtirken, \%19.05'i kararsız kalmıştır. \%32.54'ü ise görüşlerinin alındığını ifade etmiştir.

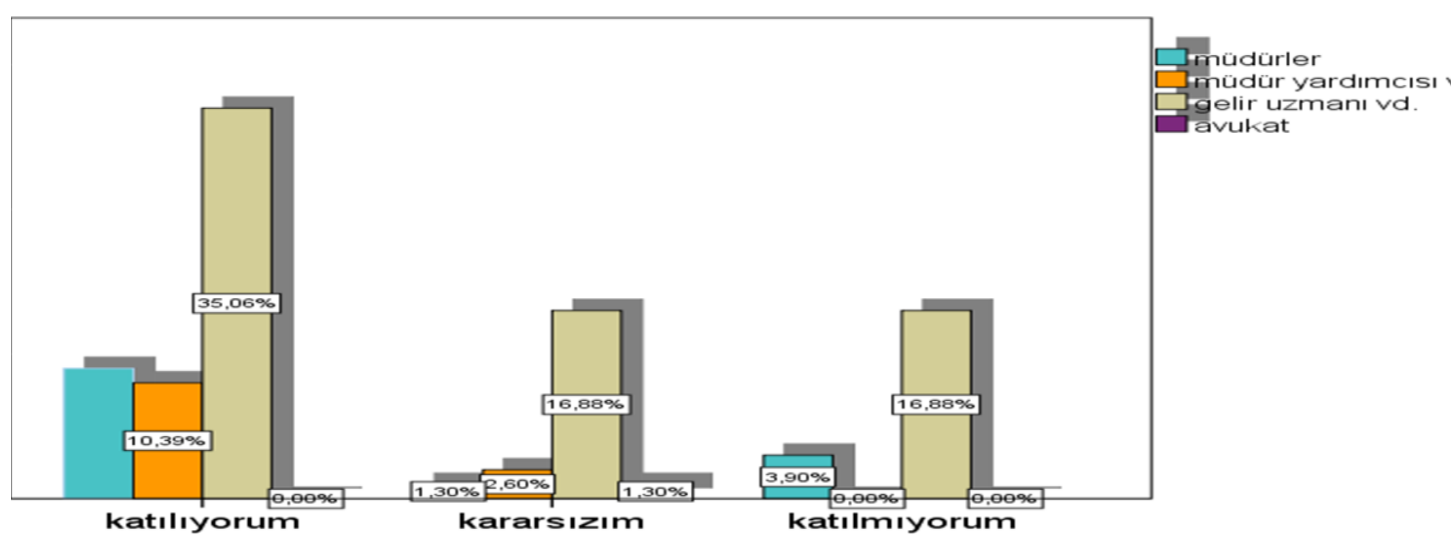

Şekil 21. Birimimizdeki Değişiklerde Astlarımın Görüşünü Alırım

Vergi işlemlerinin uygulayıcıların kurum içi esnekliğin oluşturulması, fikir alış verişinin tesis edilmesi ve işbirliğinin kuvvetlendirilmesi için astlarında görüşünün alınması karar olma konusunda esnekliği olumlu etkileyen faktörlerdendir. Ankete katılan müdürlerin \% 1.9'u kararsız kalırken; \%3.90'1 astlarının görüşünü almadığını ifade etmiştir. \%11.20'si astlarının görüşünü aldığııı belirtmişlerdir. Müdür yardımcılarının \%2.60'1 kararsız kalırken; \%10.39'u astlarının görüşlerini aldıklarını söylemişlerdir. Gelir uzmanlarının \%16.88'i kararsız kalırken yine \%16.88'i de astlarının görüşlerini almadıklarını belirtmiştir. \%35.06's1 ise astlarının görüşlerini aldıklarını ifade etmiştir. 


\section{Sonuç}

Yönetişimin en belirgin özelliği; yönetimde kararların alınması aşamasında merkezi yönetimin yanında yerel kamu kurum ve kuruluşlarınında aktif bir şekilde sürece dahil edilmesinin gerçekleştirmektir. Yönetilen/yönlendirilen vatandaş yerine, vatandaşların çeşitli sorumluluklar ve görevler üstlendiği bir yönetim anlayışını hakim kılmaktır.

Yönetişim kavramının Kamu Yönetimi literatüründe yer edinmesiyle birlikte; halk katılımı, işbirliğini hakim kılma, ortak akılda toplanma, etkinlik ve etkililik, yönetimde açılılı, şeffaflık, hesapverilebilirlik, hukukun üstünlüğü gibi kavramlar hem kamu kurum ve kuruluşları tarafından hemde yöneticiler açısından büyük önem kazanmaya başlamıştır. Bu bağlamda devletler daha demokratik bir yönetim için yeni politika araçları geliştirmeye başlamışlardır.

Yöneten ve yönetilenlerin etkileşim içerisinde politika belirlemeleri için vatandaşa en yakın kamu yönetimi kurumlarıdan olan Gelir İdaresi Başkanlığı ve Vergi Dairelerinin yönetişimci bir yaklaşımla mükelleflerin vergiye karşı uyumunu gönüllülük esasına daynadırmak ve bunu geliştirmek için yeni vergisel politika araçları geliştirmesi önemlidir.

Vergide, mükelleflerin vergiye gönüllü uyumu yeteri düzeyde sağlanamadığı için devlet yeteri düzeyde vergi toplayamamaktadır. Bu da etkin bir kamu hizmetinin tam manasıyla sağlanmasının önündeki engellerdendir. Vergi tahsildarı olan devletle ödeyici mükelleflerin arasında esaslı bir güvenin tesis edilmesi gerekmektedir. Yönetişimin geliştirilmesi ile devlet, halk ve diğer ilgili kurum ve kuruluşların vergi politikalarının belirlenmesi konusunda, karşıllklı etkileşim içerisinde uzlaşma sağlanması, katılımın, şeffaflığın ve hesapverilebilirliğin etkinleştirilmesi mükellefin vergiye gönüllü uyumunu artıracaktır. 


\section{KAYNAKÇA}

DEMIRCI, M. (2012) "Yönetişim Perspektifinde Kent Planlaması", Yönetişim ve Yönetim Ekseninde Kamu Yönetimi, Edit.: Fatma Neval Genç (Ekin Yayınevi, Bursa.

DEMIRCI, M. (2013) "Yönetişim, Otorite ve Meşruiyet", Yönetişim ve Yönetim Ekseninde Kamu Yönetimi, Edit.: Fatma Neval Genç (Ekin Yayınevi, Bursa).

DPT, (2007) Dokuzuncu Kalkınma Planı Özel İhtisas Komisyonu, DPT Yayınları, Ankara.

ÇUKURÇAYIR, M. AKIF ve H. Tuğba EROĞLU (2012) "Yönetişim Yaklaşımı ve Türkiye'de Kent Konseyleri", Yönetişim ve Yönetim Ekseninde Kamu Yönetimi, Edit.: Fatma Neval Genç (Ekin Yayınevi, Bursa).

ERYILMAZ, B. (2013) Kamu Yönetimi, Umuttepe Yayınları, Kocaeli.

ERYILMAZ, B. (1999), Kamu Yönetimi, Erkam Matbaacılık, İstanbul.

FIDAN, Y. (2011) "Yönetimden Yönetişime Kavramsal Bir Bakış", Yalova Sosyal Bilimler Dergisi, Sayı 1, ss. 6-7.

GÖYMEN, K. (2000), “Türkiye'de Yerel Yönetimler ve Yönetişim: Gereksinmeler, Önermeler, Yönelimler”, Çă̆daş Yerel Yönetimler Dergisi, C.9, Sayı:2, Ankara: TODAİE, ss.3-13.

KAHRAMAN, Y. LEVENT V. SEZAI Ö. (2012) "Yönetişim Anlayışı ve Değerlerin Yönetim Kültürüne Etkileri”, Yönetişim ve Yönetim Ekseninde Kamu Yönetimi, Edit.: Fatma Neval Genç (Ekin Yayınevi).

OKÇU, M. (2012), "Değişen Dünyayı Anlamak İçin Önemli Bir Kavram: Yönetişim” içinde: Yönetişim ve Yönetim Ekseninde Kamu Yönetimi, Ed: Fatma Neval GENÇ, Bursa, Ekin Basım Yayın Dağıtım, ss: 9-29.

ÖZER, M. A. (2006) "Yönetişim Üzerine Notlar”, Sayıştay Dergisi, Sayı 63, ss.5989, http://www.sayistay.gov.tr/yayin/dergi/icerik/der63m4.pdf

ÖZER, M. A. (2005), Yeni Kamu Yönetimi, Teoriden Uygulamaya, Platin Yayınları, Birinci Bask1, Ankara.

ŞAYLAN, G. 2000, "Kamu Yönetimi Disiplininde Bunalım ve Yeni Açılımlar Üzerine Düşünceler”, Amme İdaresi Dergisi, Cilt 33, Sayı 2. 
TESEV, (2008) İyi Yönetişim El Kitabı

TODAİE, (1998) Kamu Yönetimi Sözlüğü, TODAİE Yayınları.

YÜKSEL, M. (2000) "Yönetişim Kavramı Üzerine”, Ankara Barosu Dergisi, Sayı 3, $145-159$,

http://www.ankarabarosu.org.tr/siteler/ankarabarosu/tekmakale/20003/5.pdf 